\title{
UNDERSTANDING CONSUMPTION PATTERNS
}

by

Kenneth W Clements and

Saroja Selvanathan

DISCUSSION PAPER 92.13

JULY 1992

ISSN 0811-6067

ISBN 0-86422-204-1 


\title{
UNDERSTANDING CONSUMPTION PATTERNS*
}

\author{
by \\ Kenneth $\mathrm{W}$ Clements \\ Economic Research Centre \\ Department of Economics \\ The University of Western Australia \\ and \\ Saroja Selvanathan \\ School of Commerce and Administration \\ Griffith University \\ and \\ Economic Research Centre \\ Department of Economics \\ The University of Western Australia
}

* We are grateful to Dongling Chen and Daranee Chenhall for their help in producing this paper; and to Antony Selvanathan for comments. Clements is pleased to acknowledge the support of an ARC grant. Section 4 and 5 of this paper draw on Clements, E.A. Selvanathan and S. Selvanathan (1992). 


\section{Abstract}

The analysis of consumer demand is one of the major successes of economics as it represents the near perfect marriage of theory and econometrics. This paper reviews, distils and systematises some of the major empirical findings on consumption patterns, concentrating in particular on the more recent (and, in some cases, more controversial) evidence. One of the key conclusions of the paper is that on the basis on new methods, the hypotheses of homogeneity, symmetry and preference independence are not at such wide variance with the data as was once thought to be the case. 
TABLE OF CONTENTS

1. Introduction .........................

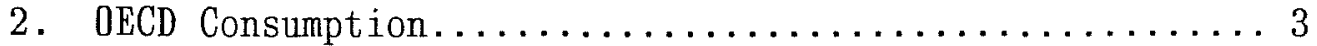

3. Divisia Variances...................... 9

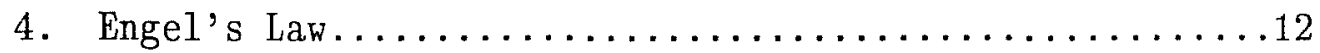

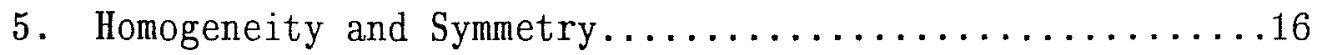

6. Preference Independence...................... 22

7. The Validity Preference Independence.............25

8. Are Tastes Constant?.........................

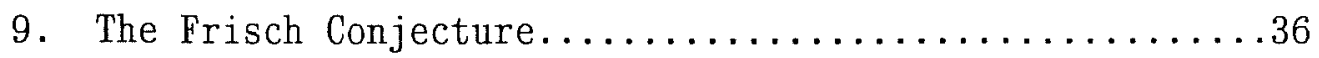

10. Some Further International Consumption Data..........39

11. The Linear Expenditure System.................44

12. More on Working's Model................... 48

13. A World Demand System........................ 55

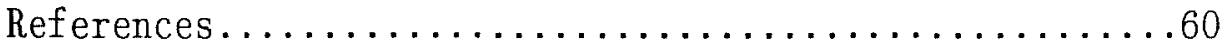


1. Characteristics of the OECD Database............... 4

2. Budget Shares of 10 Commodities for 18 Countries....... 5

3. Prices of 10 Commodities and Divisia Price Index for 18 Countries......................... 6

4. Per Capita Quantities Consumed of 10 Commodities and Divisia Volume Index for 18 Countries......... 8

5. Divisia Price Variances in 18 Countries..............10

6. Divisia Quantity Variances in 18 Countries............11

7. Divisia Price-Quantity Correlations in 18 Countries......13

8 Previous Estimates of Working's Income Coefficient

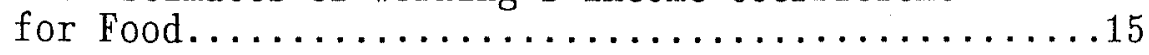

9. Percentage Rejections of Homogeneity and Symmetry........19

10. Ranks of Test Statistics for Homogeneity and Symmetry....21

11. Frequency Distributions of Income and Price Elasticities of 10 Commodities in 18 Countries.....28

12. Joint Frequency Distribution of Income and Price Elasticities of 10 Commodities in 18 Countries.....29

13. Ranks of Test Statistic for Preference Independence......32

14. Quality of Budget Share Predictions in OECD Countries and Australian States................35

15. Characteristics of the LPW Database................41

16. Budget Shares of 8 Commodities for 13 Countries.........41

17. Prices and Per Capita Quantities Consumed of

8 Commodities for 13 Countries.................42

18. Divisia Moments in 13 Countries..................43

19. First Set of Marginal Shares and Income Elasticities of 8 Commodities for 13 Countries................46

20. Marginal Shares and Budget Shares of Food for

13 Countries................................ 51 
21. Estimates of Working's Income Coefficients from

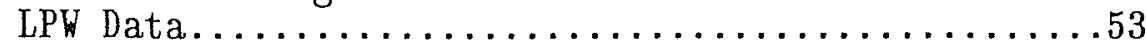

22. Second Set of Marginal Shares and Income Elasticities of 8 Commodities for 13 Countries................54

23. Quality of Predictions of Demand Equations for 8 Commodities in 13 Countries................58

\section{LIST OF FIGURES}

1. Budget Share of Food Against Scaled Total Consumption Expenditure Per Capita in 1975 for 34 Countries.....15

2. Price Elasticities Against Income Elasticities for 10 Commodities............................. 30 


\section{Introduction}

The study of consumption patterns is important for a number of reasons. First, as total consumption absorbs more than 70 percent of GDP in most countries, it is the largest of the macroeconomic aggregates, thus having great significance for the state of the economy as a whole and business conditions. Second, the pattern of

consumption contains a wealth of useful information regarding economic welfare and living standards. Closely allied to this is that as consumption (both current and future) is the ultimate objective of all economic activity and economic systems (mercantilists notwithstanding), in a fundamental sense consumption patterns are an objective way of measuring and assessing economic performance. Finally, an understanding of the price-responsiveness of consumption is of crucial importance for a host of microeconomic policy issues including public-utility pricing, the measurement of distortions, optimal taxation and the treatment of externalities.

It is partly for these reasons that the analysis of consumption has attracted the attention of some of the best minds in economics and econometrics. Additional reasons which account for the extent of sophisticated econometric analysis of consumption patterns include advances in econometric methodology and computing technology, as well as the availability of large-scale databases, both time series and cross sectional (Theil, 1980). But perhaps the most important is the near perfect marriage of theory and econometrics offered by consumer demand, a situation almost unparalleled in any other field of economics. The utility-maximising theory of the consumer gives rise to demand equations which can be aggregated over individuals to yield 
market demand curves which, under certain conditions (much weaker than usually believed), have more or less the same properties, enabling them to be applied to aggregate data. The hypotheses derived from utility theory such as homogeneity and symmetry can then be tested econometrically, so that there is a smooth transition from theory to application.

Major book-length works on the theory and measurement of consumer demand include Barnett (1981), Bewley (1986), Deaton (1975), Deaton and Muellbauer (1980a), Goldberger (1987), Lluch, Powell and Villiams (1977), Phlips (1974), Powell (1974), Theil (1975/76), Theil and Clements (1987), Theil, Chung and Seale (1989), and Theil and Suhm (1981). Survey articles of this area are provided by Barten (1977), Blundell (1988), Brown and Deaton (1972) and Deaton (1986).

The objective of this paper is to review, distil and systematise some of the major empirical findings on consumption patterns, concentrating in particular on the more recent (and, in some cases, more controversial) evidence. In order to make the paper accessible to nonspecialists, the exposition is kept as nontechnical as possible. We start by using price-quantity data for the OECD to introduce indexes of consumption patterns. Then follows a discussion of Engel's law (and its modern extension) and recent evidence on homogeneity and symmetry. Later parts of the paper deal with preference independence, the issue of the constancy of tastes and aspects of functional form of demand equations. 


\section{OECD Consumption}

In this and the next section, which draw on S. Selvanathan (1988a) and Stening (1985), we introduce some basic concepts by using consumption data from most of the 0ECD countries. Table 1 gives some broad charactistics of the database. There are 18 countries with a bit less than 20 annual observations in most.

Let $p_{i t}$ be the price and $q_{i t}$ the per capita quantity consumed of good $i$ during year $t$. Let there be $n$ goods, so that total expenditure is $\mathbb{M}_{t}=\Sigma_{i=1}^{n} p_{i t} q_{i t}$ and the proportion of total expenditure devoted to commodity $i$ is $w_{i t}=p_{i t} q_{i t} / M_{t}$. This $w_{i t}$ is called the budget share of good i. For brevity, we shall refer to $\mathbf{M}$ as "income". Table 2 presents the budget shares at sample means for each commodity in the 18 countries. For example, looking at the sixth row we see that, on average, Australians spend 19 percent of their income on food, 9 percent on beverages, 9 percent on clothing, 16 percent on housing and so on. The last row of the table presents the budget share of each commodity averaged over the 18 countries. As can be seen, the average 0ECD consumer spends 24 percent of income on food; and food, housing and transport together occupy about 50 percent of the total in most countries.

The log-change in the price of $i$ is defined as $D p_{i t}=$ $\log \mathrm{p}_{\mathrm{it}}-\log \mathrm{p}_{\mathrm{i}, \mathrm{t}-1}$. When multiplied by 100 , this log-change is approximately the annual percentage change. Columns 2-11 of Table 3 contain the mean price log-changes. The last row reveals that, on average, all prices grow between 6 and 9 percent per annum. The Divisia price index is a budget-share-weighted average of the price log-changes, 
Table 1

Characteristics of the OECD Database

Country

(1)

$$
\begin{aligned}
& \text { Sample } \\
& \text { period }
\end{aligned}
$$

$$
\begin{gathered}
\text { Sample } \\
\text { size }
\end{gathered}
$$$$
\text { International }
$$$$
\text { dollars }
$$

(3)
(4)
Number of commodity groups

(4) with US $=100$

(5)

(6)

\begin{tabular}{lrrrrr}
\hline & & & & \\
1. US & $1960-1981$ & 21 & 7132 & 100 & 10 \\
2. Canada & $1960-1981$ & 21 & 6788 & 95 & 10 \\
3. Sweden & $1964-1981$ & 17 & 6749 & 95 & 10 \\
4. Switzerland $1960-1981$ & 21 & 6082 & 85 & 9 \\
5. Denmark & $1966-1981$ & 15 & 5969 & 84 & 10 \\
6. Australia & $1960-1981$ & 21 & 5919 & 83 & 10 \\
7. France & $1964-1981$ & 17 & 5864 & 82 & 10 \\
8. Germany & $1960-1981$ & 21 & 5758 & 81 & 8 \\
9. Belgium & $1960-1981$ & 21 & 5554 & 78 & 10 \\
10. Norway & $1964-1981$ & 17 & 5419 & 76 & 10 \\
11. Netherlands & $1952-1977$ & 25 & 5321 & 75 & 10 \\
12. Iceland & $1960-1973$ & 13 & 5201 & 73 & 10 \\
13. Finland & $1960-1977$ & 17 & 5192 & 73 & 10 \\
14. Austria & $1964-1981$ & 17 & 4994 & 70 & 10 \\
15. Japan & $1970-1981$ & 11 & 4905 & 69 & 8 \\
16. UK & $1964-1981$ & 17 & 4601 & 65 & 10 \\
17. Spain & $1964-1977$ & 13 & 4032 & 57 & 10 \\
18. Italy & $1964-1981$ & 17 & 3870 & 54 & \\
& & & & & \\
\hline
\end{tabular}

The GDPs in international dollars are from Summers and Heston (1984) and are computed on the basis of the purchasing powers of national currencies, not prevailing exchange rates. Sample size is after lagging. 
Table 2

Budget Shares of 10 Commodities for 18 Countries

$($ Means $\times 100)$

\begin{tabular}{|c|c|c|c|c|c|c|c|c|c|c|}
\hline Country & $\begin{array}{c}\text { 명 } \\
8 \\
0 \\
(2)\end{array}$ & 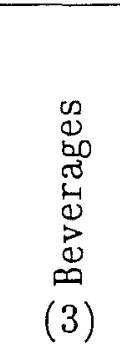 & 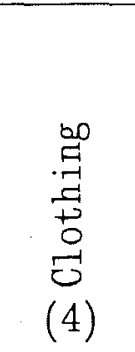 & 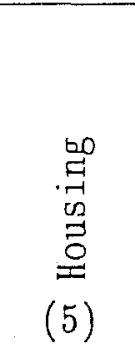 & 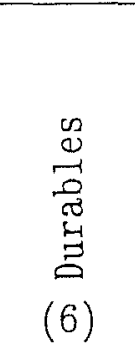 & 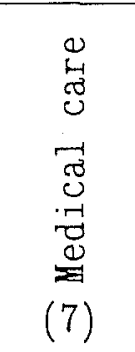 & 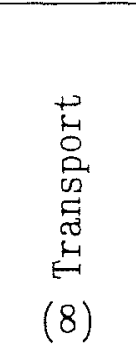 & 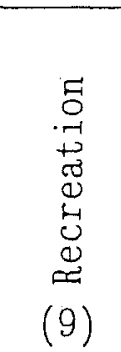 & 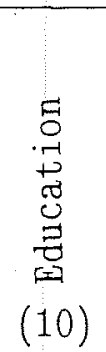 & 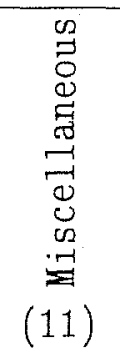 \\
\hline 1. US & 14.38 & 4.24 & 8.03 & 19.29 & 7.28 & 9.46 & 15.93 & 6.25 & 1.81 & 13.33 \\
\hline 2. Canada & 16.42 & 6.21 & 8.41 & 18.85 & 8.73 & 3.84 & 15.02 & 5.96 & 2.33 & 14.22 \\
\hline 3. Sweden & 20.72 & 7.96 & 8.41 & 22.79 & 7.66 & 2.27 & 13.65 & 9.18 & .18 & 7.18 \\
\hline 4. Switzerland & 22.73 & 9.42 & 6.77 & 18.06 & 7.80 & 6.52 & 10.99 & 9.36 & & 8.35 \\
\hline 5. Denmark & 19.18 & 9.09 & 6.97 & 20.92 & 8.98 & 1.92 & 15.04 & 7.88 & .83 & 9.19 \\
\hline 6. Australia & 19.48 & 8.96 & 9.13 & 15.77 & 8.19 & 6.04 & 15.13 & 5.71 & .69 & 10.89 \\
\hline 7. France & 21.20 & 4.69 & 8.22 & 14.41 & 10.23 & 10.50 & 11.99 & 6.05 & .29 & 12.42 \\
\hline 8. Germany & 30.38 & & 10.36 & 15.79 & 12.04 & 2.68 & 13.06 & 7.44 & & 8.55 \\
\hline 9. Belgium & 23.11 & 6.95 & 7.53 & 15.72 & 14.14 & 6.74 & 10.67 & 3.98 & .23 & 10.93 \\
\hline 10. Norway & 23.45 & 7.56 & 9.97 & 14.54 & 8.86 & 4.20 & 13.31 & 7.68 & .54 & 9.89 \\
\hline 11. Netherlands & 26.20 & 6.38 & 14.78 & 10.81 & 12.48 & 6.67 & 6.67 & 3.41 & 3.10 & 9.50 \\
\hline 12. Iceland & 23.50 & 7.86 & 10.66 & 19.06 & 10.00 & 6.07 & 12.13 & 5.24 & .44 & 5.05 \\
\hline 13. Finland & 28.24 & 8.62 & 8.26 & 14.36 & 7.51 & 2.54 & 13.60 & 5.92 & 1.44 & 9.49 \\
\hline 14. Austria & 22.06 & 7.29 & 11.37 & 11.99 & 8.89 & 3.49 & 13.36 & 5.67 & .35 & 15.54 \\
\hline 15. Japan & 27.45 & & 7.76 & 16.78 & 6.76 & 8.92 & 8.97 & 9.05 & & 14.32 \\
\hline 16. UK & 18.92 & 6.26 & 8.40 & 18.20 & 7.78 & .85 & 13.13 & 7.88 & 1.98 & 16.50 \\
\hline 17. Spain & 38.53 & 3.51 & 10.58 & 13.99 & 8.55 & 4.62 & 9.50 & 4.28 & 2.02 & 8.87 \\
\hline 18. Italy & 30.85 & 5.69 & 9.41 & 12.94 & 6.79 & 3.73 & 10.48 & 7.05 & .43 & 12.62 \\
\hline Mean & 23.71 & 6.92 & 9.16 & 16.35 & 9.04 & 5.05 & 12.37 & 6.56 & 1.11 & 10.94 \\
\hline
\end{tabular}




\section{Table 3}

Prices of 10 Commodities and Divisia Price Index for 18 Countries

$($ Mean log-changes $\times 100)$

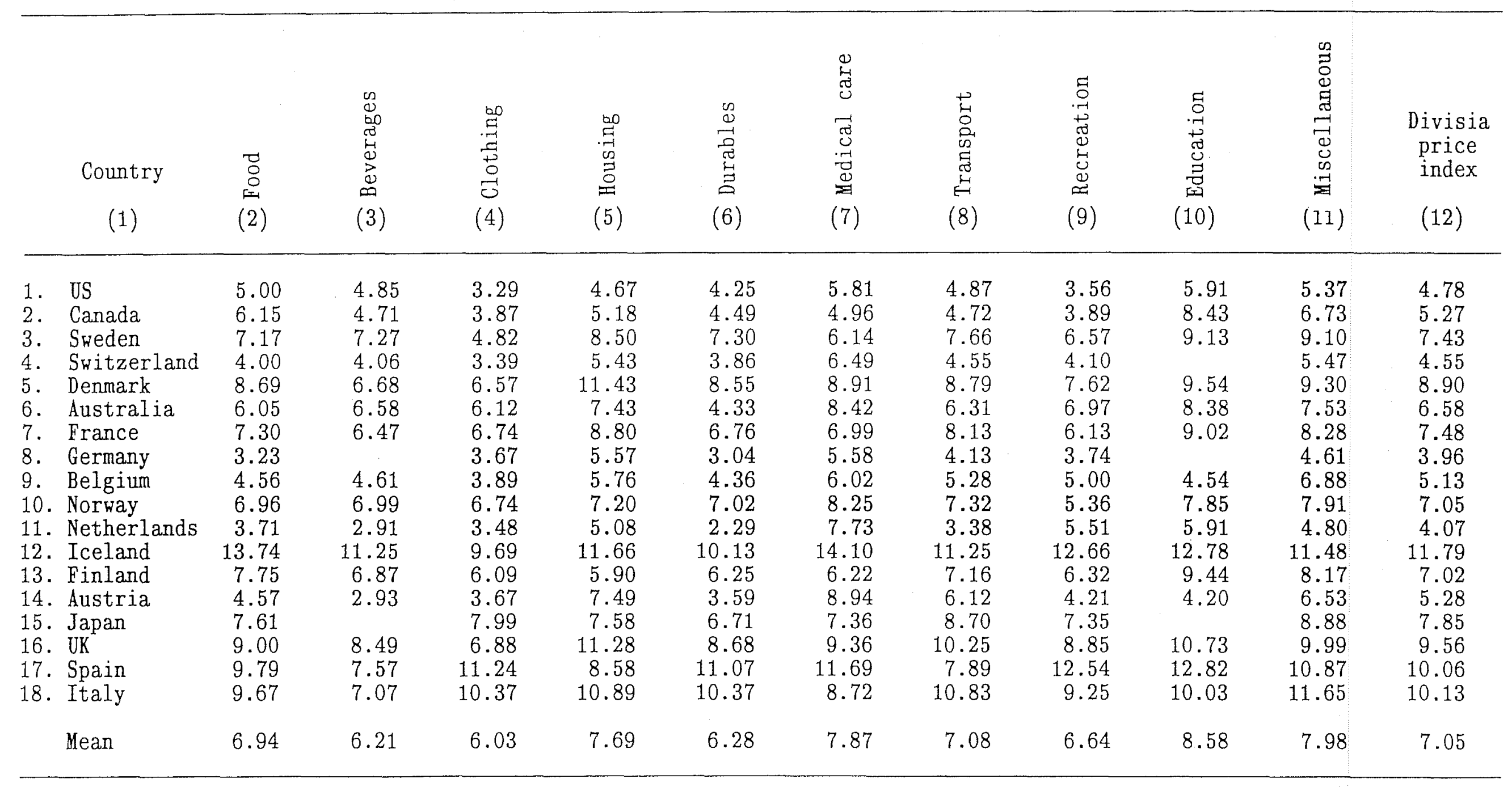




$$
D P_{t}=\sum_{i=1}^{n} \bar{w}_{i t} D p_{i t}
$$

where $\overline{\mathrm{w}}_{i t}=1 / 2\left(\mathrm{w}_{i t}+\mathrm{w}_{i, t-1}\right)$ is the arithmetic average of the budget share of commodity $i$ in years $t-1$ and $t$. Column 12 of Table 3 gives the mean of (2.1) for each country.

Columns 2-11 of Table 4 present the means of $D q_{i t}=\log q_{i t}-\log q_{i, t-1}$, the log-change in per capita consumption of $i$. Note from the last row that on average transport and recreation grow the fastest (4.9 and 4.5 percent per annum), while food has the lowest growth rate (1.4 percent). The index (2.1) measures the overall growth in prices. The analogous Divisia volume index is defined as

$$
D q_{t}=\sum_{i=1}^{n} \bar{w}_{i t} D q_{i t}
$$

This measures the overall growth in per capita consumption and is given in column 12 of Table 4. The last entry in this column indicates that per capita consumption as a whole increases by 3.0 percent per annum on average in the OECD. 
Table 4

Per Capita Quantities Consumed of 10 Commodities

and Divisia Volume Index for 18 Countries

(Mean log-changes $\times 100$ )

\begin{tabular}{|c|c|c|c|c|c|c|c|c|c|c|c|}
\hline $\begin{array}{c}\text { Country } \\
\text { (1) }\end{array}$ & $\begin{array}{c}\text { व } \\
8 \\
0 \\
01 \\
(2)\end{array}$ & 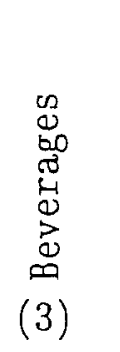 & 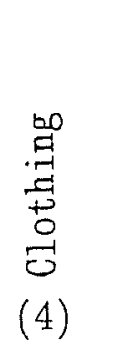 & $\begin{array}{c}\underset{0}{.7} \\
.0 \\
0 \\
0 \\
(5)\end{array}$ & 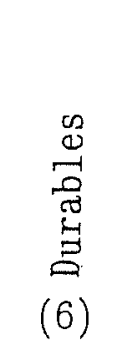 & 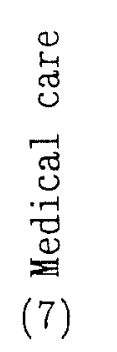 & 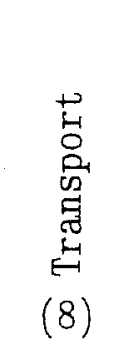 & 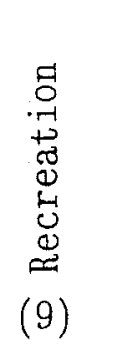 & 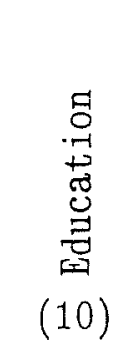 & 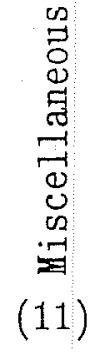 & $\begin{array}{c}\text { Divisia } \\
\text { volume } \\
\text { index } \\
\text { (12) }\end{array}$ \\
\hline US & .60 & 1.41 & 2.33 & 2.97 & 1.64 & 4.49 & 2.80 & 4.10 & 3.33 & 1.77 & 2.43 \\
\hline Canada & .91 & 2.57 & 3.12 & 3.17 & 3.02 & .22 & 4.17 & 6.27 & 4.20 & 2.79 & 2.87 \\
\hline Sweden & .50 & .80 & 2.66 & 2.35 & 1.18 & 3.02 & 2.06 & 4.53 & 3.17 & -.95 & 1.71 \\
\hline Switzerland & 1.72 & 1.57 & .75 & 2.08 & .62 & 2.85 & 3.63 & 2.98 & & 2.79 & 2.13 \\
\hline Denmark & .17 & 1.43 & .59 & 3.23 & -1.01 & 1.50 & 1.49 & 3.34 & 8.53 & .75 & 1.42 \\
\hline Australia & 1.35 & 1.03 & .71 & 3.54 & 4.45 & 1.23 & 3.49 & 4.33 & -2.40 & 1.95 & 2.37 \\
\hline France & 1.62 & 1.37 & 1.71 & 4.89 & 3.31 & 6.68 & 4.65 & 5.37 & 2.43 & 3.20 & 3.57 \\
\hline Germany & 2.02 & & 2.36 & 3.24 & 3.51 & 1.45 & 5.69 & 3.90 & & 3.77 & 3.15 \\
\hline Belgium & 1.53 & 2.58 & 2.76 & 2.80 & 4.20 & 5.13 & 4.52 & 4.04 & 1.98 & 2.98 & 3.11 \\
\hline Norway & 1.35 & 2.08 & 1.40 & 3.43 & 3.21 & 2.14 & 4.06 & 5.56 & 1.26 & 2.17 & 2.68 \\
\hline Netherlands & 2.22 & 4.39 & 3.19 & 3.93 & 6.91 & 5.53 & 7.52 & 4.07 & 5.15 & 5.20 & 4.34 \\
\hline Iceland & 1.64 & 5.11 & 5.65 & 2.54 & 8.12 & 7.20 & 8.58 & 5.92 & 4.54 & 8.56 & 5.07 \\
\hline Finland & 1.77 & 4.89 & 1.62 & 3.60 & 5.41 & 6.43 & 6.48 & 6.18 & 1.60 & 5.58 & 3.86 \\
\hline Austria & 1.90 & 2.34 & 4.26 & 4.29 & 3.61 & 2.62 & 5.58 & 4.35 & 1.94 & 1.98 & 3.27 \\
\hline Japan & 1.50 & & 1.47 & 4.93 & 1.58 & 6.07 & 4.10 & 3.26 & & 3.40 & 3.13 \\
\hline $\mathrm{UK}^{\mathrm{T}}$ & .15 & 1.48 & 2.52 & 1.87 & 1.58 & .90 & 2.81 & 3.65 & 2.10 & 1.70 & 1.76 \\
\hline Spain & 2.82 & 4.01 & 3.00 & 3.79 & 3.44 & 9.24 & 10.66 & 5.31 & 4.24 & 5.72 & 4.40 \\
\hline Italy & 2.20 & 3.15 & 2.81 & 2.80 & 3.90 & 6.82 & 5.71 & 3.98 & 1.61 & 3.65 & 3.33 \\
\hline Mean & 1.44 & 2.51 & 2.39 & 3.30 & 3.26 & 4.08 & 4.89 & 4.51 & 2.70 & 3.17 & 3.04 \\
\hline
\end{tabular}




\section{Divisia Variances}

The Divisia price and volume indexes, defined by equations (2.1) and (2.2), are budget-share-weighted first-order moments of the price and quantity log-changes. The corresponding second-order moments are the Divisia variances,

$$
\Pi_{t}=\sum_{i=1}^{n} \bar{w}_{i t}\left(D p_{i t}-D P_{t}\right)^{2}, \quad K_{t}=\sum_{i=1}^{n} \bar{w}_{i t}\left(D q_{i t}-D q_{t}\right)^{2} .
$$

These variances measure the degree to which the prices and quantities of the individual goods change disproportionately. When all the prices and quantities change proportionately, these two variances vanish.

Tables 5 and 6 present these variances. Comparing these two tables, we see that the quantity variances systematically exceed the corresponding price variances. This pattern agrees with the results of Clements (1982, 1983), Meisner (1979b), E. A Selvanathan (1987), Theil (1967) and Theil and Suhm (1981) and seems to have the status of an empirical regularity. Another empirical regularity is that higher inflation (i.e., DP) is associated with a larger disperion of relative prices (II); for a survey of the literature on inflation and relative price variability, see Marquez and Vining (1984).

The Divisia price-quantity covariance and correlation are

$$
\Gamma_{t}=\sum_{i=1}^{n} \bar{w}_{i t}\left(D p_{i t}-D P_{t}\right)\left(D q_{i t}-D Q_{t}\right), \quad \rho_{t}=\frac{\Gamma_{t}}{\sqrt{\Pi_{t} K_{t}}}
$$




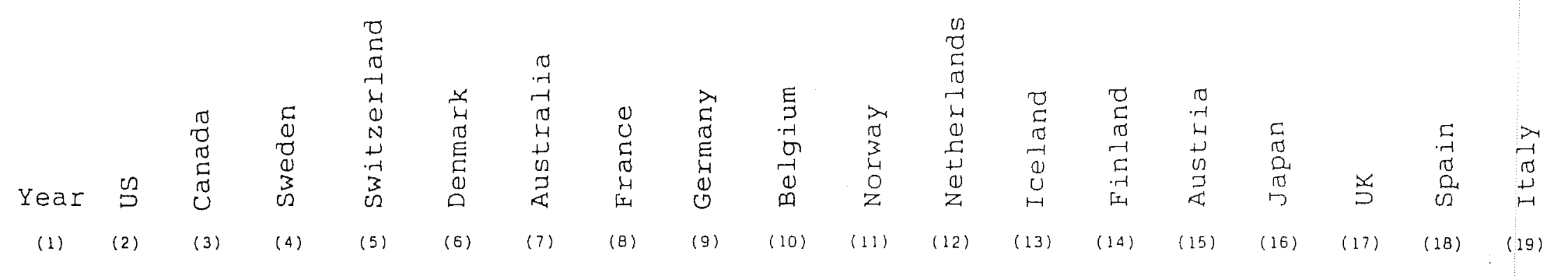

\begin{tabular}{|c|c|c|c|c|c|c|c|c|c|c|c|c|c|c|c|c|c|c|}
\hline 1953 & - & - & - & - & - & - & - & - & - & - & .34 & - & - & - & - & - & - & - \\
\hline 1954 & - & - & - & - & - & - & - & - & - & - & 1.18 & - & - & - & - & - & - & - \\
\hline 1955 & - & - & - & - & - & - & - & - & - & - & .21 & & - & - & - & - & - & - \\
\hline 1956 & $\because$ & - & - & - & - & - & - & - & - & - & .93 & - & - & - & - & - & - & - \\
\hline 1957 & - & - & - & - & - & - & - & - & - & - & .49 & - & - & & & - & - & - \\
\hline 1958 & - & - & - & - & - & - & - & . & - & - & .84 & -. & & & - & - & - & - \\
\hline 1959 & - & - & - & - & - & - & - & - & . & - & .09 & - & - & - & - & - & - & - \\
\hline 1960 & - & - & - & - & - & - & - & - & - & - & .86 & - & - & - & - & - & - & - \\
\hline 1961 & .03 & .08 & - & .25 & - & .72 & - & .45 & 1.82 & - & .10 & 1.39 & .28 & - & - & - & - & - \\
\hline 1962 & .07 & .07 & - & .12 & - & .95 & - & .17 & .59 & - & .08 & 3.56 & .38 & - & - & - & - & - \\
\hline 1963 & .03 & .15 & - & .24 & - & .89 & - & .18 & .96 & - & .18 & 3.18 & .47 & - & - & - & - & - \\
\hline 1964 & .82 & .17 & - & .26 & - & .27 & - & .21 & .18 & - & .67 & 2.29 & 1.39 & - & - & - & - & - \\
\hline 1965 & .04 & .19 & .17 & .32 & - & .47 & .17 & .18 & 1.53 & .19 & .37 & 1.00 & .87 & .35 & - & .38 & .97 & .15 \\
\hline 1966 & .22 & .35 & .32 & .15 & - & .13 & .18 & .23 & .65 & .20 & .64 & 2.03 & .39 & .24 & - & .13 & .20 & .08 \\
\hline 1967 & .26 & .34 & .32 & .50 & 1.15 & .19 & .32 & .41 & .22 & .37 & .95 & .26 & .56 & .50 & - & .11 & .72 & .18 \\
\hline 1968 & .11 & .31 & .15 & .46 & .64 & .22 & .38 & .90 & .15 & .12 & .45 & .92 & 3.36 & .58 & - & .20 & .91 & .19 \\
\hline 1969 & .12 & .22 & .51 & .29 & .38 & .63 & .15 & .29 & .14 & .16 & .57 & 6.08 & .05 & .19 & - & .08 & .72 & .05 \\
\hline 1970 & .07 & .40 & .19 & .25 & .62 & .52 & .11 & .09 & .49 & .32 & .79 & 2.45 & .22 & 3.16 & - & .17 & .88 & .13 \\
\hline 1971 & .16 & .34 & .21 & .22 & .68 & .56 & .10 & .19 & .36 & .22 & .97 & 2.16 & .17 & .51 & .39 & .29 & .37 & .23 \\
\hline 1972 & .15 & .35 & .42 & .41 & .50 & .16 & .14 & .08 & .45 & .08 & .67 & 3.79 & .33 & .34 & .41 & .47 & .84 & .34 \\
\hline 1973 & 1.48 & 1.72 & .39 & .59 & 1.25 & .96 & .28 & .04 & .51 & .09 & .49 & 2.69 & .25 & .69 & 1.68 & .99 & .59 & .52 \\
\hline 1974 & .62 & 1.07 & 2.19 & .23 & 1.09 & 1.54 & .74 & .43 & .76 & .45 & 1.02 & - & 1.84 & 1.04 & 2.82 & .46 & .88 & 1.77 \\
\hline 1975 & .33 & .47 & .34 & .25 & .24 & 1.65 & .20 & .05 & .88 & .90 & .90 & - & 1.87 & .37 & .75 & 1.01 & .54 & .91 \\
\hline 1976 & .44 & .95 & .27 & .72 & .79 & .66 & .25 & .06 & .54 & .07 & .55 & - & .91 & .52 & .47 & .36 & 1.11 & 1.13 \\
\hline 1977 & 30 & .83 & .42 & .02 & .34 & .44 & .28 & .11 & .51 & .07 & .64 & - & 1.45 & .35 & .40 & .18 & 1.56 & .67 \\
\hline 1978 & .40 & .98 & .62 & .41 & .30 & .77 & .06 & .08 & .27 & .32 & - & - & - & .45 & .81 & .40 & - & .43 \\
\hline 1979 & .47 & .27 & .64 & .85 & 1.83 & .42 & .24 & .43 & .76 & .25 & - & - & - & .40 & .24 & .54 & - & .46 \\
\hline 1980 & .96 & .18 & .47 & .25 & .79 & .35 & 1.01 & .16 & 1.76 & .55 & - & - & - & .51 & .42 & 1.17 & - & 1.00 \\
\hline 1981 & .40 & .53 & .42 & .28 & .43 & .29 & .20 & .23 & 3.45 & 1.10 & - & - & - & .69 & .03 & 2.20 & - & .16 \\
\hline Mean & .36 & .47 & .47 & .34 & .73 & .61 & .28 & .24 & .81 & .32 & .60 & 2.45 & .87 & .64 & .77 & .54 & .79 & .49 \\
\hline
\end{tabular}

All entries are to be divided by 1000 . 


\section{Divisia Quantity Variances in 18 Countries}

\begin{tabular}{|c|c|c|c|c|c|c|c|c|c|c|c|c|c|c|c|c|c|c|}
\hline Year & ص & 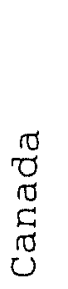 & 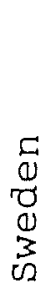 & 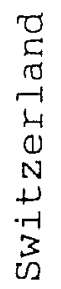 & 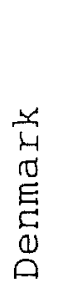 & 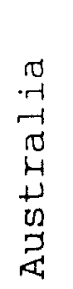 & 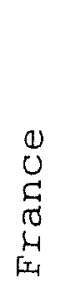 & 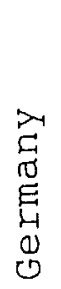 & 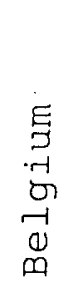 & $\begin{array}{l}2 y \\
0 \\
3 \\
.4 \\
0 \\
z\end{array}$ & 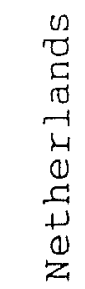 & $\begin{array}{l}0 \\
0 \\
0 \\
0 \\
0 \\
U \\
H\end{array}$ & 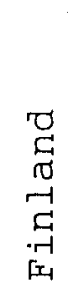 & 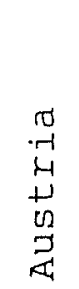 & $\begin{array}{l}\Sigma \\
\sigma \\
\sigma \\
\sigma \\
\sigma\end{array}$ & 㟔 & 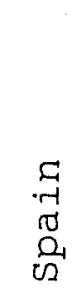 & 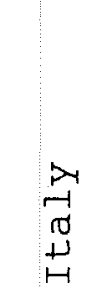 \\
\hline (1) & (2) & (3) & (4) & (5) & $(6)$ & (7) & (B) & (9) & (10) & (11) & (12) & (13) & (14) & (15) & (16) & (17) & (18) & (19) \\
\hline
\end{tabular}

\begin{tabular}{|c|c|c|c|c|c|c|c|c|c|c|c|c|c|c|c|c|c|c|}
\hline 1953 & - & - & - & - & - & - & - & - & - & - & 2.10 & - & - & - & - & - & - & - \\
\hline 1954 & - & - & - & - & - & - & - & - & - & - & 1.94 & - & - & - & - & - & - & - \\
\hline 1955 & - & - & - & - & - & - & - & - & - & - & 2.21 & - & - & - & - & - & - & - \\
\hline 1956 & - & - & - & - & - & - & - & - & - & - & 1.86 & - & - & - & - & - & - & - \\
\hline 1957 & - & - & - & - & - & - & - & - & - & - & 1.16 & - & - & - & - & - & - & - \\
\hline 1958 & - & - & - & - & - & - & - & - & - & - & 2.35 & - & - & - & - & - & - & - \\
\hline 1959 & - & - & - & - & - & - & - & - & - & - & 1.42 & - & - & - & - & - & - & - \\
\hline 1960 & - & - & - & - & - & - & - & - & - & - & .60 & - & - & - & - & - & - & - \\
\hline 1961 & .63 & 8.64 & - & .89 & - & .55 & - & .62 & 1.45 & - & .60 & 2.69 & 2.07 & - & - & - & - & - \\
\hline 1962 & .72 & .57 & - & .65 & - & 2.35 & - & .81 & .25 & - & .68 & 7.51 & 1.29 & - & - & - & - & - \\
\hline 1963 & .44 & .63 & - & .28 & - & 3.22 & - & .51 & .52 & - & .48 & 11.38 & 1.74 & - & - & - & - & - \\
\hline 1964 & .34 & .47 & - & .66 & - & .48 & - & .56 & 1.23 & - & 3.35 & 5.52 & 3.86 & - & - & - & - &.- \\
\hline 1965 & .30 & -.63 & .83 & .30 & - & .19 & .52 & .81 & .50 & .54 & 2.18 & 1.41 & 4.49 & .84 & - & .66 & 1.72 & .50 \\
\hline 1966 & .46 & .87 & .71 & .30 & - & .57 & .41 & .18 & .31 & .28 & 1.98 & 4.23 & .76 & .90 & - & .16 & 4.23 & .52 \\
\hline 1967 & .15 & .50 & .49 & .21 & .42 & .65 & .33 & .34 & .42 & .52 & 1.71 & 2.69 & .93 & .30 & - & .32 & .70 & 1.06 \\
\hline 1968 & .59 & .61 & 1.31 & .15 & .54 & .85 & .29 & .64 & .78 & .52 & 1.33 & 8.39 & .75 & .31 & - & .30 & 1.75 & .10 \\
\hline 1969 & .55 & .35 & .76 & .21 & 1.19 & 1.10 & .50 & 1.91 & .52 & 2.32 & 2.41 & 3.33 & 3.80 & .56 & - & .24 & .97 & .73 \\
\hline 1970 & .69 & 1.82 & .53 & .11 & .94 & .28 & .57 & 1.10 & .24 & 2.61 & 1.88 & 19.19 & .95 & 1.60 & - & .43 & .40 & .59 \\
\hline 1971 & .92 & 2.51 & 1.38 & .22 & 1.09 & .37 & .63 & .28 & .74 & 1.02 & 1.06 & 8.40 & 1.06 & 2.36 & .66 & .98 & .88 & .40 \\
\hline 1972 & .65 & 1.51 & .83 & .17 & .86 & .38 & .55 & .26 & .99 & .94 & 2.86 & 4.32 & 1.79 & 2.39 & .49 & 1.94 & 2.67 & .60 \\
\hline 1973 & 1.31 & 2.35 & 1.06 & .73 & 1.17 & 2.52 & .75 & .95 & 2.10 & .43 & 1.61 & 1.80 & 2.43 & .60 & 1.29 & 1.02 & 1.11 & 1.03 \\
\hline 1974 & 1.55 & 1.96 & 1.45 & .93 & 3.82 & 1.49 & 1.19 & .62 & 1.81 & .51 & 1.74 & - & 2.52 & 1.16 & 3.31 & 1.11 & .89 & .77 \\
\hline 1975 & .68 & .23 & .32 & 1.78 & 2.08 & 1.54 & .75 & 1.21 & 2.04 & .73 & 4.38 & - & 2.95 & .45 & 1.59 & .21 & .48 & .97 \\
\hline 1976 & .54 & .35 & .40 & .47 & 1.64 & .58 & .99 & .69 & .75 & 1.39 & .52 & - & 3.15 & .61 & 1.06 & .16 & .28 & .32 \\
\hline 1977 & .31 & .67 & .73 & .35 & .55 & .56 & .44 & .88 & 1.07 & 1.30 & 1.49 & - & 2.04 & 2.32 & .63 & .44 & .39 & .56 \\
\hline 1978 & .54 & .61 & .58 & .46 & .88 & .99 & .69 & .18 & .57 & 2.85 & - & - & - & 2.21 & .97 & .71 & - & .15 \\
\hline 1979 & .36 & .27 & .13 & .21 & .33 & .25 & .32 & .16 & .88 & .72 & - & - & - & .82 & .87 & .32 & - & .66 \\
\hline 1980 & 1.21 & .38 & .46 & .13 & 1.96 & .44 & .55 & .26 & 1.75 & .68 & - & - & - & .50 & 1.41 & .41 & - & .31 \\
\hline 1981 & .26 & .23 & .61 & .34 & .44 & .16 & .41 & .43 & .75 & 1.21 & - & - & - & .45 & 1.07 & .52 & - & .69 \\
\hline Mean & .63 & 1.25 & .74 & .45 & 1.19 & .93 & .58 & .64 & 94 & 1.09 & 1.78 & 6.22 & 2.15 & 1.08 & 1.21 & .58 & 1.27 & .59 \\
\hline
\end{tabular}


These measure the co-movement of prices and quantities. As demand curves slope down, we would expect the consumer to move away from those goods which have above-average price increases and vice versa. Thus we expect $\rho$ to be negative. Table 7 presents the Divisia correlations for the OECD. Of the 322 correlations, about 75 percent are negative. The last row of the table shows that, on average, the correlations are negative for each country, as expected.

\section{Engel's Law}

One of the major empirical regularities in consumption economics is Engel's law, i.e., the budget share of food falls with increasing income, or, in other words, the income elasticity of demand for food is less than unity. The classic reference in this area is Houthakker (1957) who estimated Engel curves for a large number of household surveys; in each case food was found to be a necessity.

More recently, Theil et al. (1989) have shown that it is now possible to make a more precise statement regarding the dependence on income of the food budget share. Working (1943) observed that the budget share for food seems to be a linear function of the logarithm of income. This observation was generalized by Leser (1963) to a complete set of $\mathrm{n}$ commodities to yield

$$
w_{i}=a_{i}+\beta_{i} \log M, \quad i=1, \ldots, n \text {. }
$$




\begin{tabular}{|c|c|c|c|c|c|c|c|c|c|c|c|c|c|c|c|c|c|c|}
\hline Year & $\stackrel{0}{D}$ & $\begin{array}{l}\sigma \\
\widetilde{\sigma} \\
\underset{\sigma}{\sigma}\end{array}$ & $\begin{array}{c}\vec{D} \\
0 \\
0 \\
0 \\
0 \\
3 \\
0\end{array}$ & 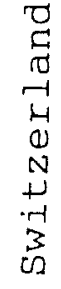 & 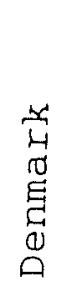 & 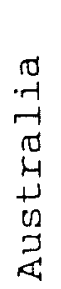 & $\begin{array}{l}0 \\
U \\
G \\
0 \\
0 \\
H \\
4\end{array}$ & $\begin{array}{l}P y \\
\Xi \\
\sigma \\
E \\
E \\
0 \\
0 \\
0\end{array}$ & $\begin{array}{c}E \\
\Xi \\
.1 \\
\sigma \\
\sigma \\
0 \\
0 \\
0\end{array}$ & $\begin{array}{l}\vec{r} \\
0 \\
3 \\
3 \\
0 \\
z\end{array}$ & 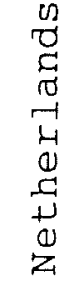 & 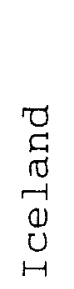 & 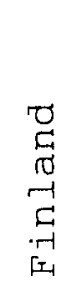 & 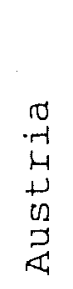 & $\begin{array}{l}\vec{\sigma} \\
\sigma \\
0 \\
\sigma \\
\sigma\end{array}$ & 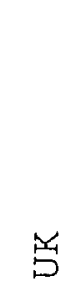 & $\begin{array}{c}\vec{G} \\
\cdot \tilde{1} \\
0 \\
0 \\
0\end{array}$ & 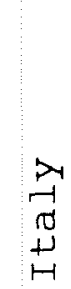 \\
\hline (1) & (2) & (3) & (4) & (5) & (6) & (7) & (8) & (9) & $(10)$ & (11) & $(12)$ & (13) & (14) & (15) & (16) & (17) & (18) & (19) \\
\hline
\end{tabular}

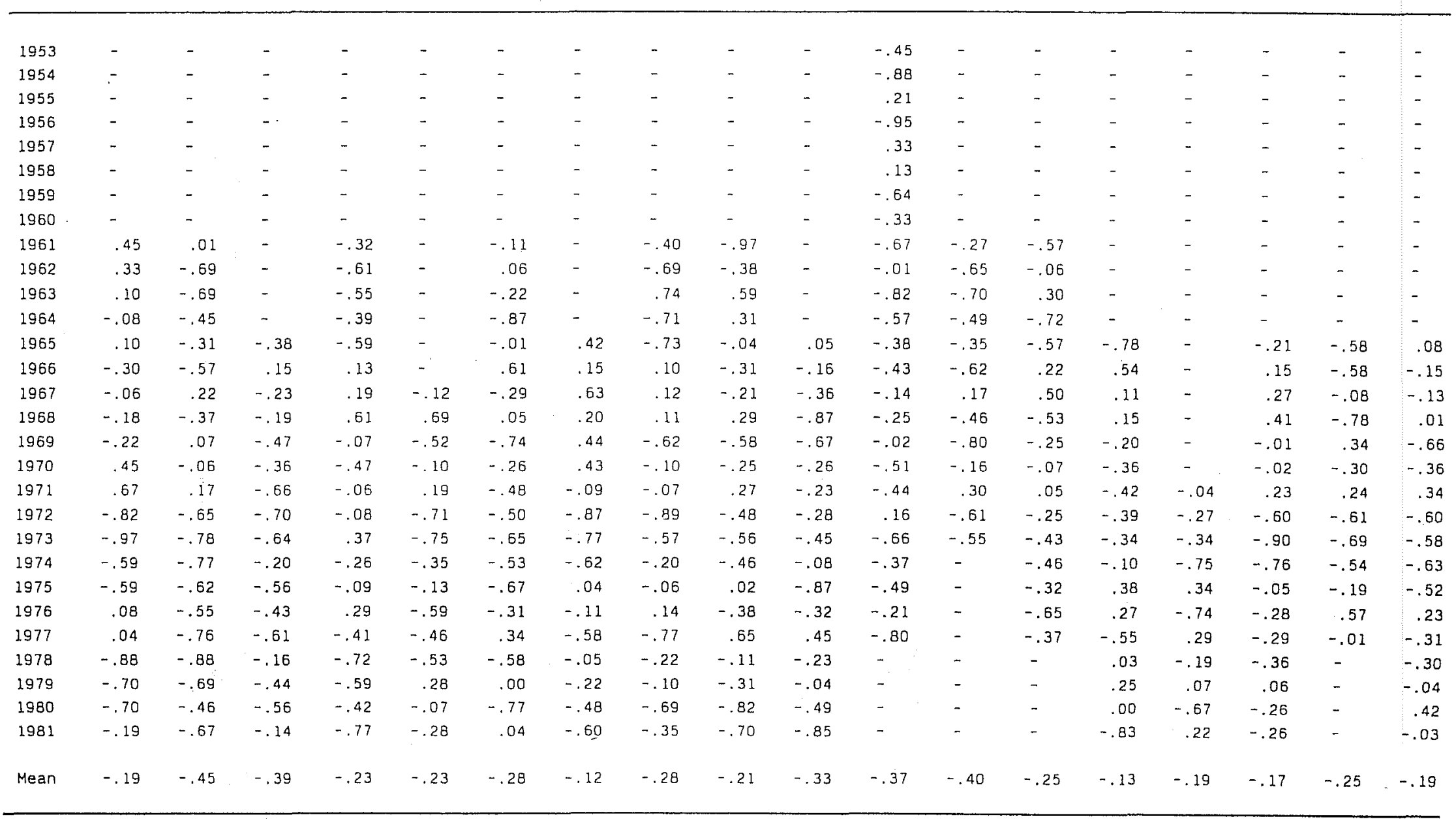


Choosing the income unit such that $\mathbb{M}=1$ for some household, $a_{i}$ is then interpreted as the budget share of $i$ for that household. The coefficient $\beta_{i}$ is interpreted as 100 times the change in the budget share of $i$ resulting from a 1 percent increase in income. We shall refer to (4.1) as Working's model.

Theil (1987a), using data from Kravis et al. (1982) for 34 countries, plots the budget share of food against the log of real per capita total consumption. Figure 1 gives such a plot (with consumption scaled such that $\mathbb{M}=1$ for the poorest country). The solid line is the LS regression line. As can be seen, the points are all scattered around a downward-sloping line which gives strong visual support for Working's model for food. The slope of the LS line is -.15 (standard error .01), which is an estimate of $\beta_{i}$ for food. This estimate does not take account of cross-country differences in the relative price of food; however, approximately the same value of $\beta_{i}$ emerges when these differences are allowed for (Theil, 1987a). The estimate of $\beta_{i}$ of -.15 is in remarkable agreement with other estimates of the food $\beta_{i}$; see Table 8 . Thus $\beta_{i}=-.15$ seems to be more or less a natural constant.

To analyze the implications of this $\beta_{i}$-estimate, consider moving from one country to another. Assume that the first country's per capita income is $\mathbb{H}$, while that of the second is $2 \mathbb{H}$. Therefore,

$$
\Delta(\log \mathbb{M})=\log 2 \mathbb{M}-\log \mathbb{M}=\log 2=.69 .
$$

From (4.1) we have

$$
\Delta w_{i}=\beta_{i} \Delta \log \mathbb{M} .
$$


Figure 1

Budget Share of Food Against Scaled Total Consumption Expendicure Per Capita in 1975 for 34 Countries

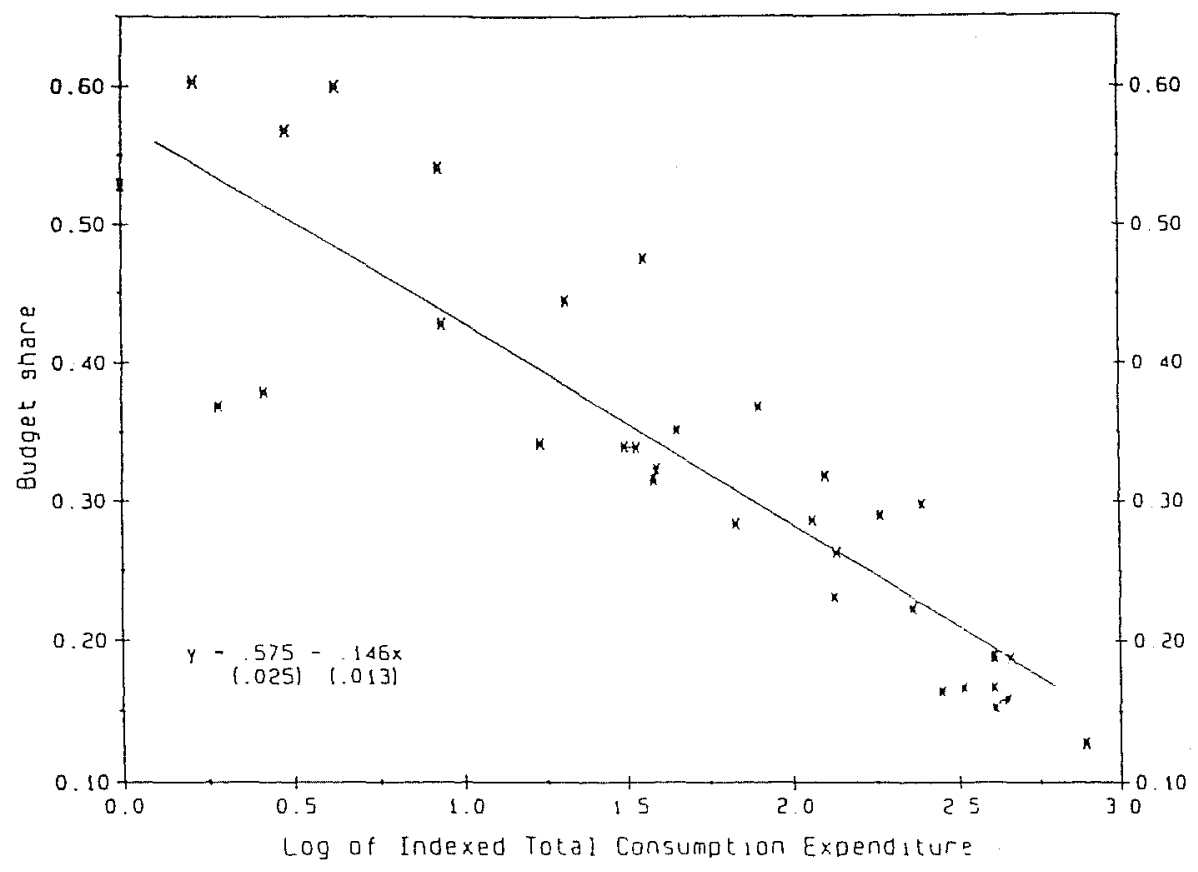

Table 8

Previous Estimates of Working's Income Coefficient for Food

\begin{tabular}{llc} 
Author(s) & Country & Estimate \\
\hline Aasness and Rodseth (1983) & Norway & -.17 \\
Blanciforti and Green (1983) & US & -.13 \\
Chung and Lopez (1988) & Spain & $-.18 \&-.16$ \\
Deaton and Muellbauer (1980b) & Britain & -.16 \\
Finke et al. (1984) & Japan & -.15 \\
Musgrove (1985) & Dominican Replublic & -.14 \\
Theil (1987a) & Cross country & -.14 to -.16 \\
Theil and Finke (1984) & Netherlands & -.13 \\
Theil et al. (1987) & China & -.13 \\
\end{tabular}


Consequently, when $\beta_{i}=-.15$ the effect of doubling income on the food budget share is

$$
\Delta \mathrm{w}_{i}=-.15 \times .69=-.10 \text {. }
$$

That is, when income doubles, the budget share declines by 10 percentage points. Theil et al. (1989) refer to this as the strong version of Engel's law.

One use of this law is to make real income comparisons across consumers or countries on the basis of the food share. As this share is obviously a pure mumber, it is directly comparable over time, countries etc., independent of inflation, exchange rates and so on. Consequently, such indirect income comparisons could be an attractive short-cut.

\section{Homogeneity and Symmetry}

The Marshallian demand equation for good $i$ is

$$
q_{i}=q_{i}\left(M, p_{1}, \ldots, p_{n}\right)
$$

If income and prices all increase proportionately, then the quantity demanded of each good should remain unchanged. That is, for $a>0$, $\mathrm{q}_{\mathrm{i}}\left(\alpha \mathrm{M}, a \mathrm{p}_{1}, \ldots, \alpha \mathrm{p}_{\mathrm{n}}\right)=\mathrm{q}_{\mathrm{i}}\left(\mathrm{M}, \mathrm{p}_{1}, \ldots, \mathrm{p}_{\mathrm{n}}\right)$, or equation $(5.1)$ is homogeneous of zero degree. This is known as the absence of money illusion or demand homogeneity and can be expressed as 


$$
\eta_{i}+\sum_{j=1}^{n} \eta_{i j}=0
$$

where $\eta_{i}=\partial\left(\log q_{i}\right) / \partial(\log \mathbb{M})$ is the income elasticity of good $i$; and $\eta_{i j}=\partial\left(\log q_{i}\right) / \partial\left(\log p_{j}\right)$ is the $(i, j)$ th uncompensated price elasticity.

The system of $n$ demand equations given by (5.1) for $i=1, \ldots, n$ also satisfies Slutsky symmetry, viz.

$$
\frac{\partial q_{i}}{\partial p_{j}}=\frac{\partial q_{j}}{\partial p_{i}} \quad i, j=1, \ldots, n
$$

where the derivatives hold real income constant. In words, the effect on beer drinking of a $\$ 1$-increase in the price of a bottle of wine is exactly equal to the response of wine consumption to the same rise in the price of a bottle of beer. Slutsky symmetry can be formulated in terms of elasticites by defining $\eta_{i j}^{\prime}=\eta_{i j}+w_{j} \eta_{i}$ as the $(i, j)$ th compensated price elasticity, where $\mathrm{w}_{j}$ is the budget share of $j$. Restriction (5.2) then becomes

$$
w_{i} \eta_{i j}^{\prime}=w_{j} \eta_{j i}^{\prime} \quad i, j=1, \ldots, n \text {. }
$$

Homogeneity and symmetry would seem to constitute highly plausible hypotheses, hypotheses that would not be expected to be at great variance with the data. Surprisingly, however, when these restrictions are tested the bulk of the evidence points towards rejection; see Barten (1977) and Keuzenkamp and Barten (1991) for surveys of these tests. 
These rejections represented a major puzzle. The response of Theil, and some others, was not to take the "evidence" too literally. He argued in Theory and Measurement of Consumer Demand that these finding reflect

\begin{abstract}
data imperfections rather then unorthodox consumer behavior. What is needed in such a situation is an explicit recognition on the part of the analyst that his data are imperfect. He should guide these data so that they yield a sensible picture. It is unavoidable that this picture of the real world will be biased toward simplicity, but it is appropriate to realize that this kind of bias is inherent in every mode1. (Theil, 1975/6, pp. 250-1 of Volume 1)
\end{abstract}

As a consequence, Theil felt comfortable simply imposing the constraints, especially homogeneity. 0thers have responded to the rejection puzzle by emphasizing dynamics (Anderson and Blundell, 1983), simultaneity (Attfield, 1985) and the use of non-stationary variables (Bewley and Elliott, 1989).

Theil's scepticism about the rejections was not shared by everyone. Some took the findings seriously and concluded that consumption theory should be rejected (see, e.g., Christensen et al., 1975). Apparently, this troubled Theil sufficiently to encourage two of his students, Laitinen and Meisner, to study the rejections by means of Monte Carlo experiments. The idea is to simulate data sets under the null, use these data to estimate the demand equations and then test homogeneity and symmetry. As the hypotheses are true by construction, the rejection rates should coincide with the nominal significance levels if the tests are working satisfactorily. 
Table 9

Percentage Rejections of Homogeneity and Symmetry

\begin{tabular}{|c|c|c|c|c|}
\hline $\begin{array}{c}\text { Number of } \\
\text { commodities, } n\end{array}$ & \multicolumn{2}{|c|}{ Rejections of homogeneity } & \multicolumn{2}{|c|}{ Rejections of symmetry } \\
\hline (1) & $\begin{array}{c}5 \text { percent } \\
(2)\end{array}$ & $\begin{array}{c}1 \text { percent } \\
(3)\end{array}$ & $\begin{array}{c}5 \text { percent } \\
(4)\end{array}$ & $\begin{array}{c}1 \text { percent } \\
(5)\end{array}$ \\
\hline 5 & 14 & 6 & 9 & 3 \\
\hline 8 & 30 & 16 & 26 & 8 \\
\hline 11 & 53 & 35 & 50 & 37 \\
\hline 14 & 87 & 81 & 96 & 91 \\
\hline
\end{tabular}

Table 9 shows Laitinen's (1978) and Meisner's (1979a) results. As can be seen from columns 2 and 3 , the rejections of homogeneity are far too high, with the rejection rate increasing with $n$, the number of commodities. The results for symmetry (columns 4 and 5 ) also indicate a substantial bias against the null, but the problems are now not quite so bad for $\mathrm{n}=5$ or 8 . The source of the problem is that these tests involve the replacement of the inverse of the disturbance covariance matrix $\boldsymbol{\Sigma}^{1}$ with its estimator $\mathrm{S}^{-1}$, the inverse of the residual moment matrix. This replacement has an asymptotic justification (when the number of observations $\mathrm{T} \rightarrow \infty$ ), but this becomes problematic when the number of commodities in the model is large relative to $\mathrm{T}$; in this case, $\mathbf{S}$ is near singular and $\mathbf{S}^{-1}$ explosive. See Theil (1987b) for further details and Bera et al. (1981) and Bewley (1983, 1986) for related contributions. 
If the standard tests are defective, how does one proceed? There are two ways of avoiding the problems associated with asymptotics. First, there is now available an exact finite-sample test for homogeneity (Laitinen, 1978). Second, Monte Carlo testing (Theil, 1987b), which is distribution-free, can be employed. This involves simulating a large number of values of the test statistic under the null hypothesis to construct its empirical distribution. The data-based value of the test statistic is then compared with this distribution, rather than its asymptotic counterpart.

S. Selvanathan (1987a) tests homogeneity and symmetry with the Monte Carlo technique for 18 OECD countries. She employs a variant of the Rotterdam model (with intercepts to take account of residual trends) and Table 10 summarizes the results. There are 100 values of each test statistic, the observed (or data-based) value plus 99 simulated values. Consequently, the hypothesis is rejected at the 5 percent level if the observed value is among the largest 5 .

Columns 2-11 of Table 10 give the ranks of the homogeneity test statistic for each commodity. Looking at the last two rows, it can be seen that durables tends to be a troublemaker. Column 14 gives the rank of the test statistic for the homogeneity of the $n$ equations jointly. As can be seen, the hypothesis is acceptable for all 18 countries except Belgium at the 5 percent level; and at the 1 percent level homogeneity cannot be rejected for any country. Column 15 of Table 10 shows that symmetry is rejected at the 5 percent level for Switzerland only. The hypothesis is acceptable in all cases at the 1 percent level.

On the basis of these new tests, the conclusion is that, on the whole, homogeneity and symmetry are not grossly incompatible with the 
Table 10

Ranks of Test Statistics for Homogeneity and Symmetry

\section{Homogeneity}

\begin{tabular}{|c|c|c|c|c|c|c|c|c|c|c|c|c|c|c|}
\hline Country & $\begin{array}{l}0 \\
8 \\
0 \\
0.1\end{array}$ & $\begin{array}{l}0 \\
0 \\
00 \\
\mathbb{7} \\
0 \\
0 \\
D \\
D \\
D\end{array}$ & 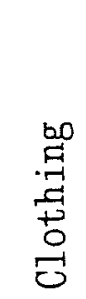 & $\begin{array}{l}\text { b0 } \\
\text { 豆 } \\
0 \\
\Xi \\
0 \\
0\end{array}$ & 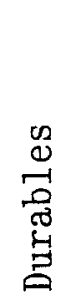 & 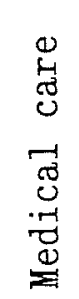 & 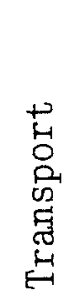 & 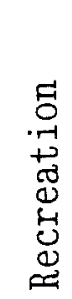 & 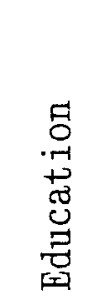 & 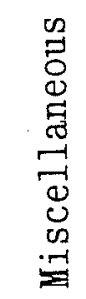 & 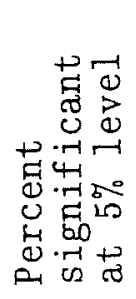 & 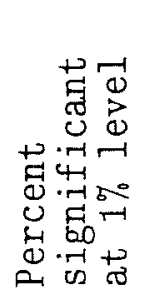 & 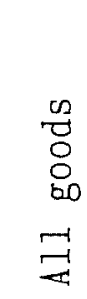 & 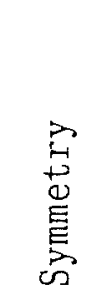 \\
\hline (1) & (2) & (3) & (4) & (5) & (6) & (7) & (8) & (9) & (10) & (11) & (12) & (13) & (14) & (15) \\
\hline
\end{tabular}

1. US

2. Canada

3. Sweden

4. Switzerland

5. Denmark

6. Australia

7. France

8. Germany

9. Belgium

10. Norway

11. Netherlands

12. Iceland

13. Finland

14. Austria

15. Japan

16. UK

17. Spain

18. Italy

$\begin{array}{rrrrrrrrrr}76 & 89 & 53 & 40 & 1 & 77 & 98 & 3 & 70 & 25 \\ 65 & 18 & 68 & 68 & 37 & 100 & 8 & 49 & 47 & 39 \\ 91 & 74 & 95 & 24 & 35 & 49 & 2 & 58 & 48 & 37 \\ 16 & 45 & 17 & 92 & 29 & 40 & 16 & 96 & - & 94 \\ 77 & 55 & 14 & 29 & 51 & 23 & 84 & 78 & 13 & 31 \\ 37 & 35 & 81 & 6 & 100 & 63 & 34 & 9 & 7 & 72 \\ 83 & 60 & 31 & 67 & 95 & 76 & 2 & 58 & 28 & 34 \\ 23 & - & 26 & 83 & 52 & 77 & 29 & 72 & - & 55 \\ 10 & 37 & 70 & 3 & 100 & 93 & 25 & 79 & 55 & 29 \\ 83 & 1 & 77 & 76 & 61 & 12 & 70 & 63 & 51 & 27 \\ 39 & 38 & 92 & 91 & 2 & 55 & 55 & 26 & 59 & 45 \\ 68 & 17 & 48 & 69 & 83 & 57 & 12 & 98 & 44 & 5 \\ 61 & 48 & 41 & 65 & 66 & 34 & 62 & 70 & 10 & 23 \\ 40 & 2 & 81 & 72 & 40 & 58 & 78 & 33 & 47 & 58 \\ 85 & - & 9 & 50 & 2 & 84 & 81 & 16 & - & 78 \\ 19 & 81 & 74 & 25 & 85 & 41 & 20 & 64 & 50 & 83 \\ 63 & 56 & 73 & 35 & 51 & 58 & 37 & 76 & 32 & 25 \\ 20 & 52 & 41 & 32 & 73 & 95 & 87 & 55 & 32 & 55\end{array}$

Percent

significant

at $5 \%$ leve 1

$\begin{array}{lllllll}6 & 28 & 6 & 17 & 11 & 0 & 0\end{array}$

$6 \quad 6$

Percent

significant

at $1 \%$ leve 1

6

$25 \quad 30$

$\begin{array}{lll}10 & 80 \quad 71\end{array}$

$\begin{array}{lll}10 & 10 & 29 \\ 10 & 0 & 75\end{array}$

$37 \quad 10$

$29 \quad 32$

94

0

0

$75 \quad 14$

8296

$25 \quad 41$
$0 \quad 6 \quad 0$

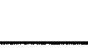


data. The previous rejections reported in the literature reflect faulty econometric procedures (the breakdown of asymptotic theory, in particular), rather a flaw in the theory of the utility-maximizing consumer .

\section{Preference Independence}

When the consumer's tastes can be described by means of a utility function which can be written as the sum of $\mathrm{n}$ sub-utility functions, each involving one good only, then tastes are said to exhibit preference independence. Formally, the utility function is of the preference independent form if

$$
u\left(q_{1}, \ldots, q_{n}\right)=\sum_{i=1}^{n} u_{i}\left(q_{i}\right),
$$

so that the marginal utility of good $i$ is independent of the consumption of $j, i \neq j$. The specification (6.1) is also known as additive preferences.

If the commodities are fairly broad groups, such as food, housing, clothing and so on, then (6.1) could be a reasonable working hypothesis as it conveys the idea that total utility is obtained from the utility derived from food and utility from housing and from clothing and so on. These broad commodity groups can be interpreted as representing the "basic wants" of the consumer and if these are truely basic wants, they could be expected to exhibit little interaction in the utility function. 
To set out the operational implications of the assumption of preference independence, we use a double-log approximation to the general demand equation (5.1):

$$
\log q_{i}=a_{i}+\eta_{i} \log M+\sum_{j=1}^{n} \eta_{i j} \log p_{j},
$$

where $\eta_{i}$ is the income elasticity of $i$ and $\eta_{i j}$ is the uncompensated elasticity of demand for good $i$ with respect to the price of $j$. Let $\log \mathrm{P}=\sum_{\mathrm{i}=1}^{\mathrm{n}} \mathrm{w}_{i} \log \mathrm{p}_{\mathrm{i}}$ be the Divisia price index in levels, $\log Q=\log \mathbb{M}-\log \mathrm{P}$ be (the logarithm of) real income and $\eta_{\mathrm{ij}}^{\prime}$ the $(i, j)^{\text {th }}$ compensated price elasticity. Then, using the Slutsky equation $\eta_{i j}=\eta_{i j}^{\prime}-w_{j} \eta_{i}$, we can formulate (6.2) in terms of real income and compensated price elasticities,

$$
\log q_{i}=a_{i}+\eta_{i} \log Q+\sum_{j=1}^{n} \eta_{i j}^{\prime} \log p_{j} .
$$

We write $\phi$ for the reciprocal of the income elasticity of the marginal utility of income ("the income flexibility" for short) and $\theta_{i}=w_{i} \eta_{i}=\partial\left(p_{i} q_{i}\right) / \partial M$ for the $i^{\text {th }}$ marginal share, with $\sum_{i=1}^{n} \theta_{i}=1$. This $\theta_{i}$ answers the question "If income rises by one dollar, how much of this is spent on commodity i?" The utility function (6.1) then implies that the price elasticities take the form (see, e.g., Clements, 1987)

$$
\eta_{i j}^{\prime}=\phi \eta_{i}\left(\delta_{i j}-\theta_{j}\right) \quad i, j=1, \ldots n
$$

where $\delta_{i j}$ is the Kronecker delta $\left(\delta_{i j}=1\right.$ if $i=j,=0$ otherwise $)$. 
We define $\log \mathrm{P}^{\prime}=\sum_{\mathrm{i}=1}^{\mathrm{n}} \theta_{i} \log \mathrm{p}_{i}$ as the Frisch price index, which has marginal shares as weights. Using (6.4), the substitution term in (6.3) then becomes

$$
\sum_{j=1}^{n} \eta_{i j}^{\prime} \log p_{j}=\phi \eta_{i} \sum_{j=1}^{n}\left(\delta_{i j}-\theta_{j}\right) \log p_{j}=\phi \eta_{i}\left(\log p_{i}-\log p^{\prime}\right)
$$

so that the demand equation for good $i$ takes the form

$$
\log q_{i}=a_{i}+\eta_{i} \log Q+\phi \eta_{i} \log \left[\frac{p_{i}}{\mathrm{p}^{\prime}}\right]
$$

As can be seen, only the own relative price, $\log \left(\mathrm{p}_{\mathrm{i}} / \mathrm{P}^{\prime}\right)$, appears in the demand equation. The "unrestricted" system of demand equations, (6.3) for $i=1, \ldots, n$, contains $n^{2}$ price elasticities $\eta_{i j}^{\prime}$; by contrast, (6.5) for $i=1, \ldots, n$ contains only one additional parameter $\phi$.

The own-price elasticity of demand for good $i$ in (6.5) is

$$
\frac{\partial\left(\log q_{i}\right)}{\partial\left[\log \frac{p_{i}}{p^{\prime}}\right]}=\phi \eta_{i}
$$

Strictly speaking, because the Frisch deflator is used in the relative price term of (6.5), this is a Frisch elasticity which holds constant the marginal utility of income. It can be converted to the more conventional real-income-constant elasticity by simply taking out the term $\log \mathrm{p}_{\mathrm{i}}$ from the Frisch index $\log \mathrm{P}^{\prime}=\Sigma_{\mathrm{i}=1}^{\mathrm{n}} \theta_{\mathrm{i}} \log \mathrm{p}_{\mathrm{i}}$; this elasticity then takes the form $\partial\left(\log q_{i}\right) / \partial\left(\log p_{i}\right)=\phi \eta_{i}\left(1-\theta_{i}\right)$, which is approximately equal to its Frisch counterpart $\phi \eta_{i}$ if the marginal share $\theta_{i}$ is small (as it is likely to be since $\sum_{i=1}^{n} \theta_{i}=1$ ). 
It is clear from (6.1) that preference independence is the simplist possible specification of tastes. The simplicity and transparency of the assumption is also clear from the demand equation (6.5) which focuses exclusively on the role of income and the own-relative price. As a general principle, simplicity is usually to be preferred to complexity in the sense that if the world can be understood with a simple (not to be confused with simplistic!) model, then there is no point to persuing more complicated alternatives. This is merely a matter of scientific efficiency.

\section{The Validity Preference Independence}

In the previous section we argued that the assumption of preference independence leads to an attractive simplification of demand equations. There are two distinction justifications for this assumption (Clements, 1987): (i) The economic justification in terms of preference independence being plausible when the commodities in question are broad aggregrates; and (ii) the statistical justification that the assumption reduces the number of unknown coefficients to be estimated from the order of $\mathrm{n}^{2}$, which for even moderate-sized systems can be too large for precise estimates, to something much less. However, whether it is truely legitimate to invoke the assumption of preference independence is largely an emprical question. In this section we discuss some empirical evidence on this topic.

We return to (6.5), the demand equation for good $i$ under preference independence, and write it as 


$$
\log q_{i}=a_{i}+\eta_{i} \log Q+\gamma_{i} \log \left[\frac{p_{i}}{P^{\prime}}\right],
$$

where

$$
\gamma_{i}=\phi \eta_{i}
$$

is the own-price elasticity of demand. As (7.2) holds for $i=1, \ldots, n$, it is clear that preference independence implies that price elasticities are proportional to income elasticities with $\phi$ the (negative) factor of proportionality. In other words, luxurious are more price elastic than necessities (Deaton, 1974, Pigou, 1910).

The proportionality between income and price elasticities may, at first, seem counter intuitive. The income elasticity reflects the luxuriousness of the good, while the size of the price elasticity is an indication of the availability of substitutes. As these are difference dimensions of the good, one may be tempted to argue that there should be no a priori relationship between the elasticities. On the other hand, however, it is common practice to identify as necessities those goods which the consumer cannot easily do without (e.g., food); while luxuries involve discretionary expenditure for which there are many competing uses and thus can be easily foregone or postponed (e.g., durables). This use of language points in the direction of a relationship between the two types of elasticities (Deaton, 1987).

To analyse the evidence on the proportionality relationship (7.2), S. Selvanathan (1988a) estimates (7.1) in first-difference form for 18 OECD countries (with the Frisch price index replaced with 
its Divisia counterpart). Table 11 summaries the results in the form of cross-country frequency distributions of the elasticities. As can be seen, all the income elasticities for food are less than one which supports Engel's law. Also, housing is always a necessity and durables a luxury. Finally, most of the own-price elasticities lie between 0 and -1 .

The income and price elasticities reported in Table 11 are unrestricted in that they are not constrained by (7.2). Table 12 gives the joint frequency distribution of the income and price elasticities. As can be seen, 55 percent of commodities are necessities $\left(\eta_{i} \leq 1\right)$ and $34 / 55=62$ percent of these have own-price elasticities less than one half (in absolute value). Regarding the luxuries, $30 / 45=67$ percent possess price elasticities larger than one half. Consequently, there is a distinct tendency for those commodities with lower income elasticities to also have (absolutely) smaller price elasticities and vice versa. This is prime facie evidence in favour of the (7.2).

Figure 2, from S. Selvanathan (1988a), provides another perspective on the relationship between the income and price elasticities. This plots each pair of estimates $\left\{\gamma_{i}, \eta_{i}\right\}$ averaged over the 18 countries and the solid line is the LS regression line. Here again luxuries tend to be more price elastic. See S. Selvanathan (1988a) for evidence on the proportionality relationship within each of the 18 countries. In a widely-quoted paper, Deaton (1974) carries out a similar analysis of the the elasticities derived from UK data for $n=37$ and 8 commodities. He finds no relationship between income and price elasticities and concludes "that the assumption of additive preferences is almost certain to be invalid in practice and the use 
Table 11

Frequency Distributions of Income and Price Elasticities of 10 Commodities in 18 Countries

(Percentages)

\begin{tabular}{|c|c|c|c|c|c|c|c|c|c|c|c|}
\hline Range & $\begin{array}{l}\text { 马ृ } \\
8 \\
0 \\
\text { II }\end{array}$ & $\begin{array}{l}0 \\
0 \\
0 \\
0 \\
0 \\
0 \\
0 \\
0 \\
0 \\
\infty\end{array}$ & 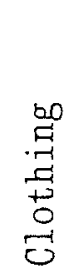 & $\begin{array}{l}b 0 \\
\text { b } \\
.7 \\
0 \\
0 \\
0 \\
0\end{array}$ & 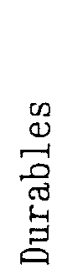 & 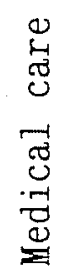 & 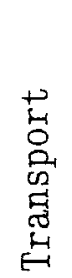 & 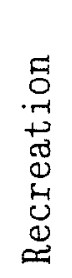 & 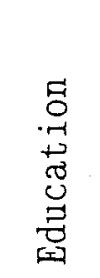 & 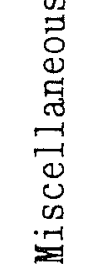 & $\begin{array}{l}n \\
8 \\
8 \\
0 \\
ت \\
\exists\end{array}$ \\
\hline (1) & $(2)$ & (3) & (4) & (5) & (6) & (7) & (8) & (9) & (10) & (11) & (12) \\
\hline
\end{tabular}

Income Elasticity $\left(\eta_{i}\right)$

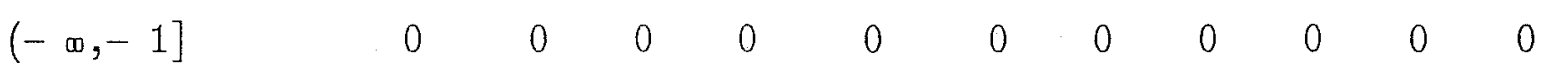

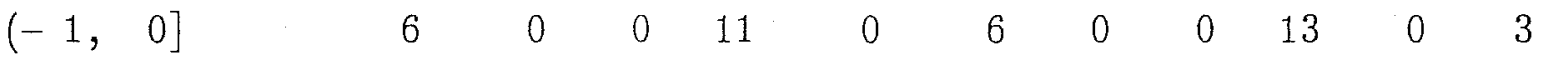

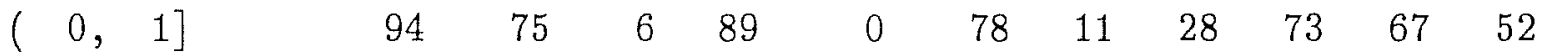

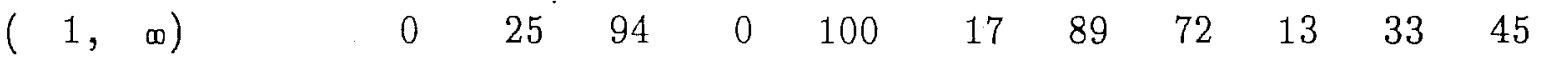

Price Elasticity $\left(\gamma_{i}\right)$

$\left(\begin{array}{llllllllllll}- \text { w, }-1] & 0 & 6 & 28 & 0 & 22 & 0 & 33 & 28 & 13 & 6 & 14\end{array}\right.$

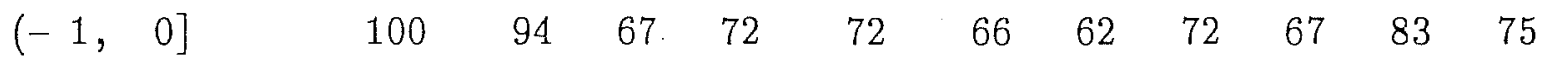

$\left(\begin{array}{llllllllllll}0,1] & 0 & 0 & 5 & 28 & 6 & 28 & 5 & 0 & 20 & 11 & 10\end{array}\right.$

$\left(\begin{array}{llllllllllll}1, \infty) & 0 & 0 & 0 & 6 & 0 & 6 & 0 & 0 & 0 & 0 & 1\end{array}\right.$


Table 12

Joint Frequency Distribution of Income and Price Elasticities of 10 Commodities in 18 Countries (Percentages)

\begin{tabular}{cccc}
\hline \multirow{2}{*}{$\begin{array}{c}\text { Income } \\
\text { elasticity } \\
\eta_{\mathrm{i}}\end{array}$} & \multicolumn{3}{c}{ Absolute value of price elasticity $\left|\gamma_{\mathbf{i}}\right|$} \\
\cline { 2 - 4 } & $\leq \frac{1}{2}$ & $>\frac{1}{2}$ & Total \\
$\leq 1$ & 34 & 21 & 55 \\
$>1$ & 15 & 30 & 45 \\
Total & 49 & 51 & 100 \\
\hline
\end{tabular}

of demand models based on such an assumption will lead to severe distortion of measurement." (Deaton, 1974, p. 346, his emphasis)

Moreover; Deaton's rejection of preference independence on the basis of indirect evidence (the proportionality of the elasticities) is consistent with a number of more direct tests; see Barten (1977) for a survey. However, these tests have only an asymptotic justification and in light of the poor performance of the asymptotic tests of homogeneity and symmetry (discussed in Section 5 above), it is appropriate to exercise caution in taking them at face value.

S. Selvanathan (1987a, 1987b) pursues this matter by developing a Monte Carlo test of preference independence. This test works in a similar manner to the Monte Carlo tests of homogeneity and symmetry discussed in Section 5. She again employs a variant of the Rotterdam 
Price Elasticities Against Income Elasticities

for 10 Commodities

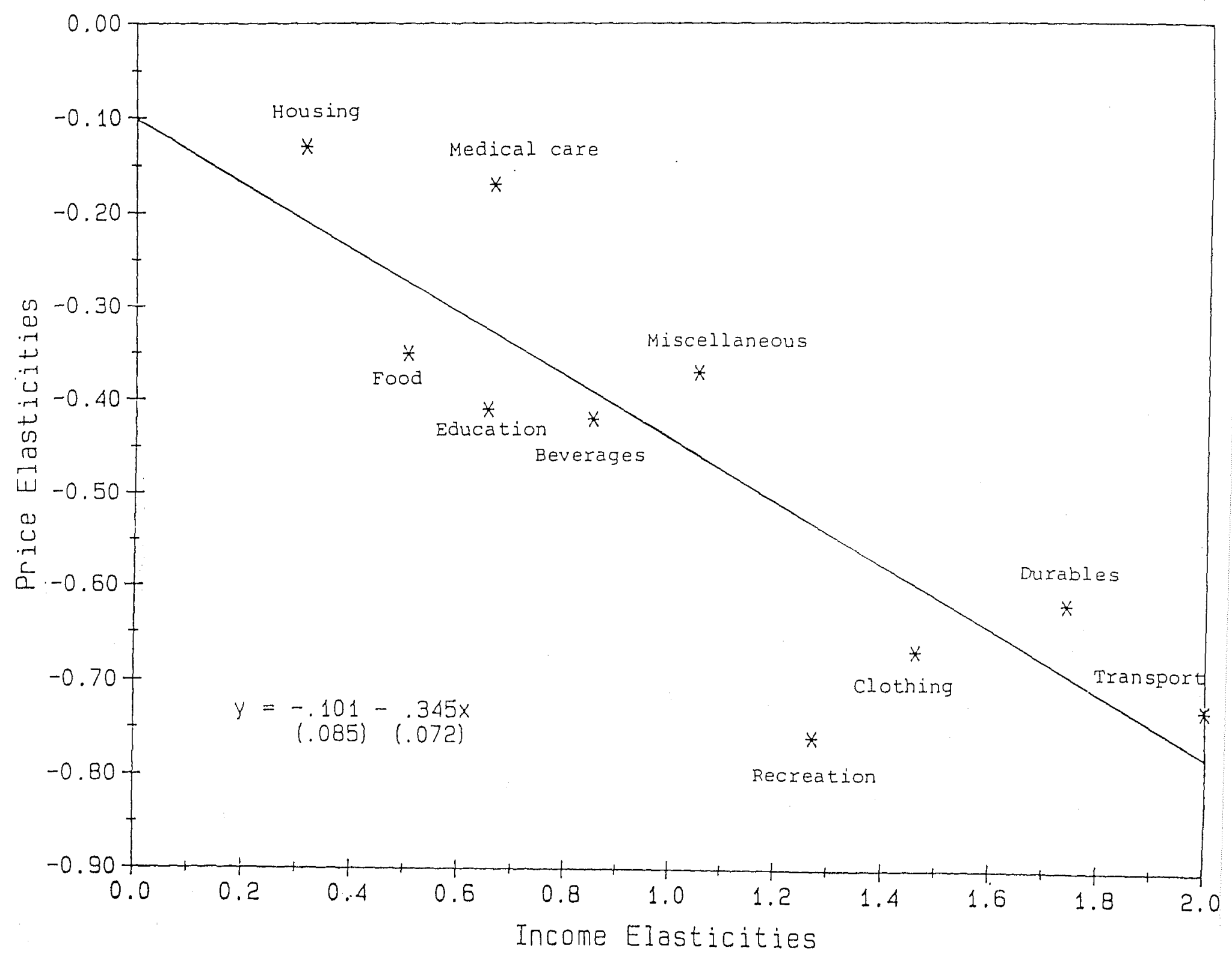


model with and without intercepts. Table 13 summarizes Selvanathan's results for 18 OECD countries. For some countries, the sample is undersized so that $\mathbf{S}$, the residual moment matrix, cannot be used as the estimator of the disturbance covariance matrix. Conseqently, a more parsimonious estimator is also used $\mathbf{\Sigma}^{*}$, which is defined in the notes to Table 13. Columns 2 and 3 of the table reveal that preference independence is rejected at the 5 percent level in 4 out of 7 countries when $\mathbf{S}$ can be used. When $\boldsymbol{\Sigma}^{*}$ is used, for all 18 countries the hypothesis cannot be rejected at the 5 percent level when intercepts are included in the model.

Whilst some qualifications to these results are required (such as the change in the ranking of the test statistic with the covariance estimator), they do nonetheless provide some tentative indications that the status of the preference independence hypothesis is not as low as was once thought. This conclusion is also supported by Selvanathan's results on the proportionality of income and price elasticities, discussed above, which contradict Deaton's (1974) earlier findings for the UK. 
Table 13

Ranks of Test Statistic for Preference Independence

Country $\frac{\text { Based on } \mathbf{S}}{\text { No intercepts With intercepts }} \quad \frac{\text { Based on } \Sigma^{*}}{\text { No intercepts With intercepts }}$

(1)

(2)

(3)

(4)

(5)

\begin{tabular}{|c|c|c|c|c|}
\hline 1. US & 100 & 100 & 58 & 70 \\
\hline 2. Canada & 98 & 96 & 23 & 15 \\
\hline 3. Sweden & - & - & 22 & 89 \\
\hline 4. Switzerland & 91 & 86 & 95 & 82 \\
\hline 5. Denmark & - & - & 47 & 58 \\
\hline 6. Australia & 86 & 70 & 93 & 92 \\
\hline 7. France & - & - & 91 & 86 \\
\hline 8. Germany & 95 & 50 & 84 & 30 \\
\hline 9. Belgium & 99 & 100 & 43 & 49 \\
\hline 10. Norway & - & - & 97 & 93 \\
\hline 11. Netherlands & 98 & 99 & 39 & 25 \\
\hline 12. Iceland & - & - & 7 & 24 \\
\hline 13. Finland & - & - & 91 & 59 \\
\hline 14. Austria & - & - & 81 & 79 \\
\hline 15. Japan & - & - & 50 & 79 \\
\hline 16. UK & - & - & 43 & 5 \\
\hline 17. Spain & - & - & 56 & 36 \\
\hline 18. Italy & - & - & 84 & 77 \\
\hline \multicolumn{5}{|l|}{ Percent } \\
\hline $\begin{array}{l}\text { significant } \\
\text { at } 5 \% \text { level }\end{array}$ & 57 & 57 & 6 & 0 \\
\hline \multicolumn{5}{|l|}{ Percent } \\
\hline $\begin{array}{l}\text { significant } \\
\text { at } 1 \% \text { level }\end{array}$ & 14 & 29 & 0 & 0 \\
\hline
\end{tabular}

$\mathrm{S}$ is the residual moment matrix; and $\mathbf{\Sigma}^{*}=\lambda^{2}\left(\boldsymbol{W}-\mathbf{w w}^{\prime}\right)$, where $\lambda$ is an unknown parameter, $\boldsymbol{W}=\operatorname{diag}[\mathbf{w}], \mathbf{v}=\left[\overline{\overline{\mathbf{w}}}_{i}\right]$ and $\overline{\overline{\mathbf{w}}}_{i}$ is the sample mean of the arithmetic average of the $i^{\text {th }}$ budget share. 


\section{Are Tastes Constant?}

Utility maximization theory usually postulates that tastes are fixed, so that it is only the observable variables income and prices that explain consumption. There is a compelling reason for treating tastes (an unobservable) as constant: As the necessarily ad hoc auxillory assumptions about the evolution of tastes are avoided, utility theory thereby has more applicability, generality and explanatory power. In a highly-influential paper, Stigler and Becker (1977) advocate treating tastes as fixed along these lines. They show that a number of examples of apparently capricious behavior (addiction, custom, tradition, fashion etc.) can in fact be reconciled with the assumption of stable preferences. Stigler and Becker (p. 89) argue that

no significant behavior has been illuminated by the assumption of differences in tastes. Instead, they, along with the assumption of unstable tastes, have been a convenient crutch to lean on when the analysis has bogged down. They give the appearance of considered judgement,yet really have only been ad hoc arguements that disguise analytical failures.

The hypothesis of stable preferences can be tested by estimating demand equations for different groups of consumers and then analysing the extent to which the parameters (such as the income and price elasticities) differ across consumers. S. Selvanathan (1987c) carries out such a test with the OECD database by estimating (i) country-specific demand equations; and (ii) common demand equations 
for all countries whereby the data are pooled across countries. The test then involves an analysis of the deterioration in the fit of the demand equations when the data are pooled. In other words, this amounts to investigating the extent to which the same demand equations can explain consumption in the different OECD countries. The upper part of Table 14 contains the results using the root-mean-squared (RMS) percentage prediction error as the goodness-of-fit criterion. (The 15 OECD countries with 10 commodity groups are used here; see Table 1). Although the RMSEs for the country-specific models (given in column 3 ) are in general a bit lower than those for the pooled model (column 4), the differences are not substantial. In addition, the countries have similar rankings with respect to the two sets of RMSEs.

Looking at the entries in row 17 of columns 3 and 4 of Table 14, the weighted means of the RMSEs are 1.87 percent for the individual country models and 1.95 percent for the pooled model. Accordingly, the average "cost" of taking tastes to be identical is $1.95-1.87=$ .08 percentage points. This is cleary quite modest and points in the direction that tastes are not too dissimilar across countries. (For a different finding, however, see Pollak and Wales, 1987.)

There are many non-economic differences between some of the OECD countries. For example, language, culture and climate differ substantially in some cases. It may thus come as a surprise to some (not Stigler and Becker!) that tastes in these countries are more or less similar. In an attempt to control for some of the non-economic factors, S. Selvanathan (1988b, Chap. 8) conducts a similar analysis with data from different regions of the same country, the six states of Australia. The lower part of Table 14 summarizes the findings and 
Table 14

Quality of Budget Share Predictions

in OECD Countries and Australian States

\begin{tabular}{cccc}
\hline Weight \\
$\begin{array}{c}\text { Country/ } \\
\text { state }\end{array}$ & $\begin{array}{c}\text { RMS percentage } \\
\text { prediction error }\end{array}$ \\
\cline { 3 - 4 } & $(2)$ & $\begin{array}{c}\text { Individual } \\
\text { country/state } \\
\text { model }\end{array}$ & $\begin{array}{c}\text { Pooled } \\
\text { country/state } \\
\text { model }\end{array}$ \\
(1) & $(3)$ & (3)
\end{tabular}

QECD countries

1. US

2. Canada

3. Sweden

4. Denmark

5. Australia

6. France

7. Belgium

8. Norway

9. Netherlands

10. Iceland

11. Finland

12. Austria

13. UK

14. Spain

15. Italy

16. Unweighted mean

17. Keighted mean

18. NSW

19. Victoria

20. Queensland

21. SA

22. WA

23. Tasmania

24. Unweighted mean

25. Weighted mean
51.34

5.14

1.84

1.01

2.74

10.30

1.81

.72

2.42

.04

.82

1.25

8.57

4.78

7.20

1.65

3.16

1.88

2.16

2.41

1.39

2.59

2.07

3.20

4.70

3.68

2.34

1.77

2.33

1.88

2.48

1.87

\section{Australian states}

38.53

27.31

14.79

8.29

8.47

2.61
2.16

2.49

3.07

2.47

2.54

3.42

2.69

2.47
1.72

3.32

1.91

2.16

2.46

1.39

2.74

2.35

3.58

4.99

3.67

2.50

1.79

2.29

2.13

2.60

1.95
2.14

2.59

2.97

2.51

2.46

3.56

2.70

2.48

The column 2 weights for the OECD countries are proportional to GDPs, in 1975 in international dollars; and the weights for the Australian states are proportional to total consumption expenditures in 1981. The RMS percentage prediction errors in columns 3 and 4 are 100 times the square root of the budget-share-weighted mean of the squared relative prediction errors of the budget shares; as an approximation, these are computed as 100 times the square root of twice the information inaccuracies. 
the result is that tastes are even more similar within a country, as expected. However, as the sample size for the states is small, it is appropriate to exercise some caution here.

\section{The Frisch Conjecture}

In Section 6 we showed that preference independence implies that the compensated price elasticities $\eta_{i j}^{\prime}$ take the form (6.4). We write that equation as

$$
\eta_{i j}^{\prime}=\phi \eta_{i}\left(\delta_{i j}-w_{j} \eta_{j}\right)
$$

where $\phi$ is the income flexibility (i.e., the reciprocal of the income elasticity of the marginal utility of income); $\eta_{i}$ is the $i^{\text {th }}$ income elasticity; $\delta_{i j}$ is the Kronecker delta $\left(\delta_{i j}=1\right.$ if $i=j,=0$ otherwise); and $w_{j}$ is the budget share of good $j$. In rewriting equation (6.4) as (9.1), we have used the definition of the income elasticity $\eta_{i}=\theta_{i} / w_{i}, \theta_{i}$ being the $i^{\text {th }}$ marginal share.

If we accept the assumption of preference independence, equation (9.1) means that we can then compute the $n \times n$ matrix of the price elasticities $\left[\eta_{i j}^{\prime}\right]$ from the value of the scalar $\phi$, the $\mathbf{n}$ income elasticities and $n$ budget shares. It is the attraction of being able to compute price elasticities in this manner that has lead equation (9.1), or a variant thereof, to be used in at least two types of applications. First, in many developing countries time-series data of sufficient length and quality are not available, so it is impossible to estimate price elasticities. But as income 
elasticities and budget shares are usually available from household surveys, equation (9.1), together with a $\phi$-value, can then be used to generate price elasticities. The second application of this equation is in computable general equilibrium models which have such a large number of commodities that the price elasticities cannot be directly estimated. For example, Dixon et al. (1982, Sec. 29.5) use this approach in a CGE model which distinguishes over 100 consumer goods.

What value of the income flexibility should be used in equation (9.1)? Our starting point for this question is Frisch's famous conjecture that $\phi$ increases in absolute value as the consumer (or country) becomes more affluent. (Frisch discusses the behavior of $1 / \phi$, which he calls the "money flexibility"; for clarity, in what follows we make the necessary translations from $1 / \phi$ to $\phi$ ). Frisch (1959, p. 189) provides the following numerical conjectures for the dependence of $\phi$ on real income:

We may, perhaps, assume that in most cases the income flexibility has values of the order of magnitude given below.

-.1 for an extremely poor and apathetic part of the population.

-.25 for the slightly better off but still poor part of the population with a fairly pronounced desire to become better off.

-.5 for the middle income bracket, "the median part" of the population.

-1.4 for the better off part of the population. 
- 10 for the rich part of the population with ambitions towards "conspicuous consumption".

It would be a very promising research project to determine the income flexibility for different countries and for different types of populations. A universal "atlas" should be constructed. It would serve an extremely useful purpose in demand analysis.

Frisch's conjecture has been tested by a number of authors. Brown and Deaton (1972) report estimates of the income flexibility from various studies and conclude that they show no evidence of a dependence on real income. Also, Brown and Deaton suggest that it would be fair to use a value of -.5 for $\phi$. DeJanvry et al. (1972) collect estimates of the income flexibility from several studies and find a statistically significant relationship between $\phi$ and income, which supports Frisch. As noted by Theil (1980), however, the validity of their conclusion is based on the uncritical acceptance of the previous estimates.

Lluch et al. (1977) use time-series data for 14 countries (developed and underdeveloped) at various levels of commodity aggregation to estimate a variant of the linear expenditure system. They find strong evidence in favor of Frisch at the four-commodity level of aggregation, but less support at the two-and one-commodity levels. S. Selvanathan $(1987 \mathrm{c}, \mathrm{d})$ uses time-series data for the OECD countries and finds that $\phi$ is unrelated to income. Selvanathan also recommends a value of about -.5 for $\phi$.

Using data for 30 countries, Theil (1987a) concludes that the sample cannot support Frisch in spite of the large income variation. 
Theil and Brooks $(1970 / 71)$ use a modified version of the Rotterdam model in which the income flexibility is a function of income. They obtain the result that the income flexibility is again unrelated to income.

This brief review indicates a lack of unanimity about the status of Frisch. It seems, however, that the broad thrust of the literature has not been too kind to Frisch's conjecture. This is possibly not unexpected given the nature of the conjecture: The income elasticity of the marginal utility of income relates to a second-order derivative of the (indirect) utility function, so that its dependence on income involves a third derivative. It is not possible for most economic data to reveal much information about such higher-order derivatives. Consequently, it is probably best to treat $\phi$ as a constant equal to around -.5 . It should be noted that the constancy of the income flexibility is not inconsistent with the idea of constant tastes discussed in the previous section.

\section{Some Further International Consumption Data}

In the earlier sections of the paper we presented consumption data for 18 OECD countries. In this section we use a different database which contains both developed and developing countries. Relative to the $0 \mathrm{ECD}$, these data exhibit more cross-country variability in income. The material for this and the next two sections is mainly from S. Selvanathan (1988b).

In a pioneering book, Lluch, Powell and Williams (1977, hereafter LPW) use data for 8 commodity groups in 17 countries. 
Table 15 presents an overview of the data for 13 of the 17 countries with countries ordered in terms of declining per capita GNP. (See S. Selvanathan, 1988b, for the reasons for not considering 4 of the LPW countries.) As can be seen, the US has the highest per capita GNP, while Korea has the lowest with only 4 percent of the US value. Table 16 presents the budget shares at sample means of the 8 commodities in each country. Note the strong tendency for the food budget share to decline with increasing GNP which is in accordance with Engel's law. The upper half of Table 17 presents the average annual price log-changes, while the lower half presents the corresponding per capita quantity log-changes.

Next, we summarize these data with Divisia indexes. Let $\overline{\mathrm{w}}_{i \mathrm{c}}$ be the budget share of $i$ for country $c$ at sample means (given in Table 16); and $\mathrm{Dp}_{\mathrm{ic}}$ and $\mathrm{Dq}_{\mathrm{ic}}$ be the mean price and quantity log-changes (Table 17). The Divisia price and volume indexes for country $c$ are then

$$
\mathrm{DP}_{\mathrm{c}}=\sum_{\mathrm{i}=1}^{8} \overline{\mathrm{w}}_{\mathrm{ic}} \mathrm{Dp}_{\mathrm{ic}}, \quad \mathrm{DQ} \mathrm{q}_{\mathrm{c}}=\sum_{\mathrm{i}=1}^{8} \overline{\mathrm{w}}_{\mathrm{ic}} \mathrm{Dq}_{\mathrm{ic}}
$$

and are presented in columns 2 and 3 of Table 18. As can be seen from the last row of the table, on average, prices in these countries increase by 3.5 percent per annum while per capita consumption grows at a slightly lower rate. Columns 4-6 of the table contain the corresponding second-order moments defined in Section 3 . 
Table 15

Characteristics of the LPV Database

\begin{tabular}{|c|c|c|c|}
\hline \multirow{2}{*}{ Country } & \multirow{2}{*}{$\begin{array}{l}\text { Sample } \\
\text { period }\end{array}$} & \multicolumn{2}{|c|}{$\begin{array}{l}\text { Per capita GNP at } \\
\text { sample midpoint }\end{array}$} \\
\hline & & $\begin{array}{c}\text { In } 1970 \\
\text { OS dollars }\end{array}$ & $\begin{array}{l}\text { (3) with } \\
\text { US }=100\end{array}$ \\
\hline (1) & (2) & (3) & (4) \\
\hline 1. US & $1955-68$ & 3669 & 100 \\
\hline 2. Sweden & $1955-68$ & 2962 & 81 \\
\hline 3. Australia & $1955-66$ & 2192 & 60 \\
\hline 4. UK & $1955-68$ & 1900 & 52 \\
\hline 5. Israel & $1959-68$ & 1468 & 40 \\
\hline 6. Italy & $1955-68$ & 1207 & 33 \\
\hline 7. Puerto Rico & $1955-67$ & 1023 & 28 \\
\hline 8. Ireland & $1955-68$ & 1014 & 28 \\
\hline 9. Greece & $1958-68$ & 676 & 18 \\
\hline 10. South Africa & $1955-68$ & 596 & 16 \\
\hline 11. Panama & $1960-68$ & 564 & 15 \\
\hline 12. Thailand & $1960-69$ & 148 & 4 \\
\hline 13. Korea & $1955-68$ & 142 & 4 \\
\hline
\end{tabular}

Source: Lluch et al. (1977, Table 3.2).

Table 16

Budget Shares of 8 Commodities for 13 Countries

$($ Means $\times 100)$

\begin{tabular}{|c|c|c|c|c|c|c|c|c|}
\hline $\begin{array}{c}\text { Country } \\
\text { (1) }\end{array}$ & 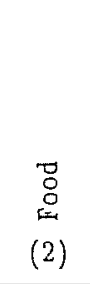 & 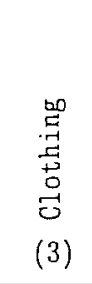 & $\begin{array}{l}\underset{20}{ \pm} \\
.7 \\
0 \\
0 \\
0 \\
(4)\end{array}$ & 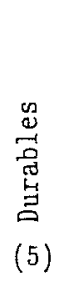 & 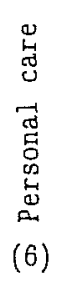 & 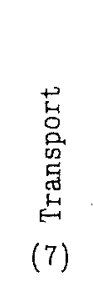 & 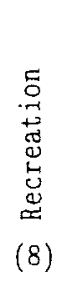 & 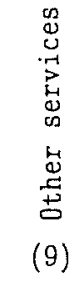 \\
\hline 1. US & 26.7 & 9.5 & 22.7 & 7.3 & 8.1 & 15.2 & 5.5 & 4.9 \\
\hline 2. Sweden & 36.6 & 11.5 & 15.9 & 7.0 & 3.7 & 14.2 & 8.9 & 2.4 \\
\hline 3. Australia & 33.3 & 11.0 & 12.7 & 7.8 & 5.7 & 13.1 & 4.3 & 12.1 \\
\hline 4. UK & 39.7 & 10.7 & 18.3 & 6.6 & 2.3 & 10.9 & 7.5 & 4.0 \\
\hline 5. Israel & 31.9 & 9.4 & 19.2 & 7.4 & 6.6 & 7.3 & 8.1 & 10.0 \\
\hline 6. Italy & 46.3 & 10.1 & 16.6 & 3.2 & 6.3 & 8.1 & 7.5 & 1.8 \\
\hline 7. Puerto Rico & 35.6 & 10.6 & 15.3 & 6.9 & 6.9 & 12.3 & 8.8 & 3.7 \\
\hline 8. Ireland & 49.2 & 10.0 & 12.8 & 5.7 & 1.3 & 8.8 & 6.3 & 5.9 \\
\hline 9. Greece & 46.8 & 12.2 & 18.3 & 3.9 & 3.6 & 6.9 & 6.1 & 2.3 \\
\hline 10. South Africa & 36.8 & 11.8 & 16.7 & 7.8 & 4.8 & 13.2 & 4.7 & 4.1 \\
\hline 11. Panama & 45.5 & 7.4 & 16.7 & 6.4 & 4.7 & 9.4 & 7.5 & 2.3 \\
\hline 12. Thailand & 57.6 & 8.4 & 8.0 & 3.2 & 5.6 & 7.9 & 7.5 & 1.8 \\
\hline 13. Korea & 59.9 & 10.4 & 11.4 & 2.8 & 4.2 & 4.7 & 4.4 & 2.2 \\
\hline 14. Hean & 42.0 & 10.2 & 15.7 & 5.8 & 4.9 & 10.2 & 6.7 & 4.4 \\
\hline
\end{tabular}

Source: Lluch et al. (1977, Table 3.3). 
Table 17

Prices and Per Capita Quantities Consumed of

8 Commodities for 13 Countries

(Mean annual 1 og-changes $\times 100)$

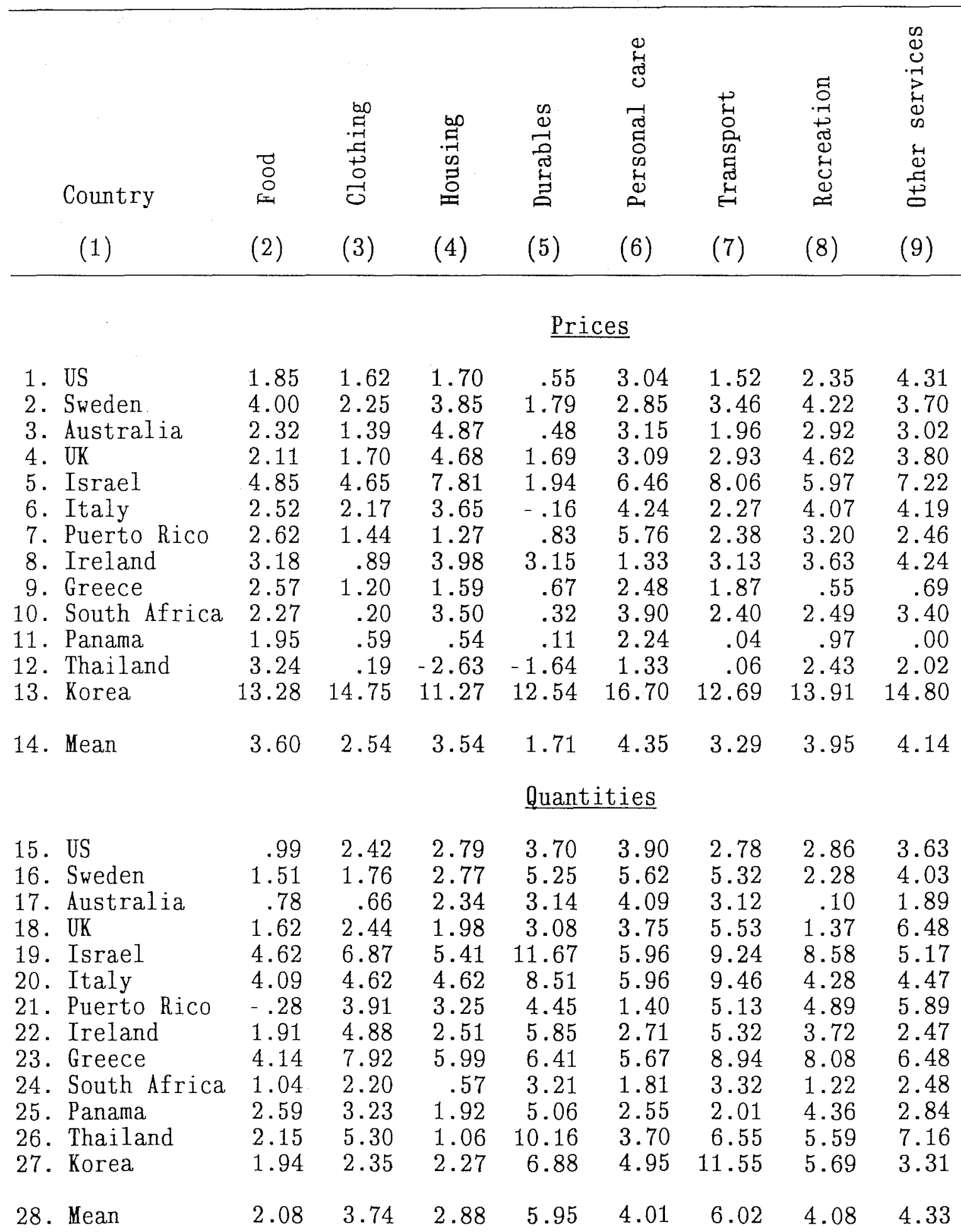

Source: Derived from Lluch et al. (1977, Tables 3.4 and 3.5); see S. Selvanathan (1988b, Chap. 1) for details. 
Table 18

Divisia Moments in 13 Countries

\begin{tabular}{lccccc}
\hline Country & $\begin{array}{c}\text { Price } \\
\text { index }\end{array}$ & $\begin{array}{c}\text { Volume } \\
\text { index }\end{array}$ & $\begin{array}{c}\text { Price } \\
\text { variance }\end{array}$ & $\begin{array}{c}\text { Quantity } \\
\text { variance }\end{array}$ & $\begin{array}{c}\text { Price- } \\
\text { quantity } \\
\text { correlation }\end{array}$ \\
(1) & $(2)$ & $(3)$ & $(4)$ & $(5)$ & $(6)$ \\
\hline 1. US & 1.89 & 2.47 & .57 & .97 & .20 \\
2. Sweden & 3.52 & 2.83 & .56 & 2.41 & -.42 \\
3. Australia & 2.51 & 1.75 & 1.28 & 1.32 & .09 \\
4. UK & 2.88 & 2.52 & 1.33 & 2.15 & .05 \\
5. Israel & 5.85 & 6.30 & 2.89 & 4.40 & -.31 \\
6. Italy & 2.82 & 4.94 & .79 & 2.53 & -.30 \\
7. Puerto Rico & 2.40 & 2.49 & 1.32 & 5.17 & -.30 \\
8. Ireland & 3.11 & 2.97 & .73 & 1.95 & -.42 \\
9. Greece & 1.93 & 5.71 & .50 & 2.86 & -.80 \\
10. South Africa & 2.23 & 1.67 & 1.24 & .96 & -.47 \\
11. Panama & 1.21 & 2.76 & .65 & .73 & -.15 \\
12. Thailand & 1.92 & 3.37 & 3.63 & 4.51 & -.38 \\
13. Korea & 13.36 & 2.93 & 1.27 & 5.11 & .05 \\
14. Mean & 3.51 & 3.29 & 1.29 & 2.70 & -.24 \\
& & &. & & \\
\hline
\end{tabular}

All entries in columns 2 and 3 are to be divided by 100 ; and those in columns 4 and 5 are to be divided by 10,000 . 


\section{The Linear Expenditure System}

Stone's (1954) linear expenditure system is probably the most popular demand system. Notable studies using this model include Deaton (1975), Goldberger and Gamaletsos (1970), Kravis et al.(1982), Lluch and Powell (1975), Lluch et al. (1977), Parks (1969), Pollak and Wales (1969) and Yoshihara (1969). In this section we set out the linear expenditure system and then present some estimates from LPW.

Our starting point is the well-known Klein-Rubin (1948) utility function,

$$
u\left(q_{1}, \ldots, q_{n}\right)=\sum_{i=1}^{n} \theta_{i} \log \left(q_{i}-\gamma_{i}\right)
$$

where $\theta_{i}$ and $\gamma_{i}$ are constants satisfying $\theta_{i}>0, \quad \sum_{i=1}^{n} \theta_{i}=1$ and $\mathrm{q}_{i}>\gamma_{i}$ for each i. Maximizing (11.1) subject to the budget constraint gives the corresponding demand equations. It is convenient to express these in expenditure form,

$$
p_{i} q_{i}=p_{i} \gamma_{i}+\theta_{i}\left[M-\sum_{j=1}^{n} p_{j} \gamma_{j}\right], \quad i=1, \ldots, n .
$$

This model is known as the linear expenditure system (LES).

The linearity of LES is attractive in its simplicity. When the $\gamma_{i}$ 's are all positive, the model has the following intuitive interpretation: The consumer first purchases the "subsistence" quantities $\gamma_{1}, \ldots, \gamma_{n}$ at a cost of $\sum_{j=1}^{n} p_{j} \gamma_{j}$. This leaves $M-\sum_{j=1}^{n} p_{j} \gamma_{j}$ of unspent income which can be called "supernumerary" 
income. Then, a fraction $\theta_{i}$ of this supernumerary income is spent on good $i$. Note also that $\theta_{i}=\partial\left(p_{i} q_{i}\right) / \partial M$ is the $i^{\text {th }}$ marginal share.

Two other aspects of LES should be noted. First, it cannot be used to test the homogeneity and symmetry hypotheses as these are built in or maintained hypotheses in this model. Second, equation (11.1), the utility function underlying LES, is of the preference independent form. As discussed in Section 6, this imposes certain restrictions on the price elasticities. But, as argued in Section 7, these restrictions may not be at great variance with the data if the model is applied to broad commodity groups.

We return to the LPW database described in the previous section. LPW use time-series data to estimate LES (or a variant thereof, Lluch's, 1973, extended linear expenditure system) for the 13 countries listed in Table 15. The model is estimated for each country independently of the others. The upper part of Table 19 presents the estimates of the marginal shares $\theta_{i c}(i=1, \ldots, 8$ goods; $c=1, \ldots, 13$ countries), while the lower part gives the implied income elasticities,

$$
\eta_{i c}=\frac{\theta_{i c}}{\overline{\bar{w}}_{i c}},
$$

with the mean budget shares from Table 16. As can be seen from the last row of Table 19, on average food and housing are necessities, clothing is a borderline case, while the remaining five other goods are luxuries. 
Table 19

First Set of Marginal Shares and: Income Elasticities of 8 Commodities for 13 Countries

\begin{tabular}{|c|c|c|c|c|c|c|c|c|}
\hline $\begin{array}{c}\text { Country } \\
\text { (1) }\end{array}$ & $\begin{array}{l}\text { 며 } \\
8 \\
0 \\
(2)\end{array}$ & 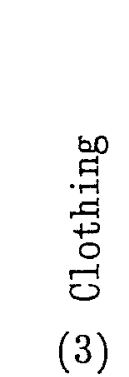 & $\begin{array}{l}60 \\
.7 \\
.7 \\
0 \\
0 \\
0 \\
(4)\end{array}$ & 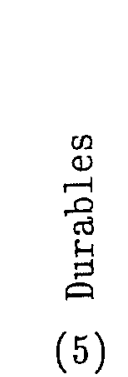 & 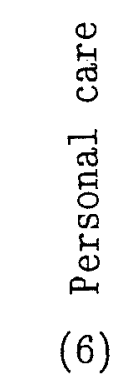 & 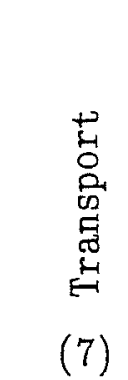 & 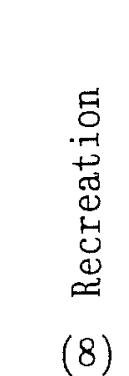 & 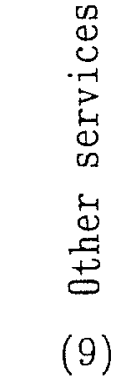 \\
\hline & \multicolumn{8}{|c|}{ Marginal shares } \\
\hline $\begin{array}{l}\text { 1. US } \\
\text { 2. Sweden } \\
\text { 3. Australia } \\
\text { 4. UK } \\
\text { 5. Israel } \\
\text { 6. Italy } \\
\text { 7. Puerto Rico } \\
\text { 8. Ireland } \\
\text { 9. Greece } \\
\text { 10. South Africa } \\
\text { 11. Panama } \\
\text { 12. Thailand } \\
\text { 13. Korea }\end{array}$ & $\begin{array}{l}.090 \\
.278 \\
.143 \\
.120 \\
.210 \\
.401 \\
.177 \\
.315 \\
.341 \\
.295 \\
.418 \\
.482 \\
.434\end{array}$ & $\begin{array}{l}.108 \\
.071 \\
.050 \\
.067 \\
.103 \\
.087 \\
.112 \\
.134 \\
.168 \\
.164 \\
.081 \\
.101 \\
.069\end{array}$ & $\begin{array}{l}.206 \\
.145 \\
.220 \\
.258 \\
.172 \\
.171 \\
.144 \\
.108 \\
.175 \\
.066 \\
.113 \\
.013 \\
.085\end{array}$ & $\begin{array}{l}.106 \\
.079 \\
.082 \\
.076 \\
.119 \\
.069 \\
.068 \\
.114 \\
.050 \\
.115 \\
.113 \\
.052 \\
.077\end{array}$ & $\begin{array}{l}.137 \\
.052 \\
.133 \\
.030 \\
.066 \\
.066 \\
.114 \\
.014 \\
.048 \\
.049 \\
.044 \\
.052 \\
.074\end{array}$ & $\begin{array}{l}.174 \\
.253 \\
.224 \\
.277 \\
.116 \\
.117 \\
.176 \\
.170 \\
.107 \\
.206 \\
.085 \\
.123 \\
.146\end{array}$ & $\begin{array}{l}.065 \\
.097 \\
.009 \\
.066 \\
.117 \\
.070 \\
.137 \\
.075 \\
.083 \\
.046 \\
.127 \\
.150 \\
.078\end{array}$ & $\begin{array}{l}.113 \\
.024 \\
.138 \\
.106 \\
.097 \\
.019 \\
.072 \\
.070 \\
.028 \\
.059 \\
.019 \\
.028 \\
.038\end{array}$ \\
\hline 14. Mean & .285 & .101 & .144 & .086 & .068 & .167 & .086 & .062 \\
\hline & \multicolumn{8}{|c|}{ Income elasticities } \\
\hline $\begin{array}{l}\text { 15. US } \\
\text { 16. Sweden } \\
\text { 17. Australia } \\
\text { 18. Uk } \\
\text { 19. Israel } \\
\text { 20. Italy } \\
\text { 21. Puerto Rico } \\
\text { 22. Ireland } \\
\text { 23. Greece } \\
\text { 24. South Africa } \\
\text { 25. Panama } \\
\text { 26. Thailand } \\
\text { 27. Korea }\end{array}$ & $\begin{array}{l}.337 \\
.760 \\
.429 \\
.302 \\
.658 \\
.866 \\
.497 \\
.640 \\
.729 \\
.802 \\
.919 \\
.837 \\
.725\end{array}$ & $\begin{array}{r}1.137 \\
.617 \\
.455 \\
.626 \\
1.096 \\
.861 \\
1.057 \\
1.340 \\
1.377 \\
1.390 \\
1.095 \\
1.202 \\
.663\end{array}$ & $\begin{array}{r}.907 \\
.912 \\
1.732 \\
1.410 \\
.896 \\
1.030 \\
.941 \\
.844 \\
.956 \\
.395 \\
.677 \\
.163 \\
.746\end{array}$ & $\begin{array}{l}1.452 \\
1.129 \\
1.051 \\
1.152 \\
1.608 \\
2.156 \\
.986 \\
2.000 \\
1.282 \\
1.474 \\
1.766 \\
1.625 \\
2.750\end{array}$ & $\begin{array}{r}1.691 \\
1.405 \\
2.333 \\
1.304 \\
1.000 \\
1.048 \\
1.652 \\
1.077 \\
1.333 \\
1.021 \\
.936 \\
.929 \\
1.762\end{array}$ & $\begin{array}{l}1.145 \\
1.782 \\
1.710 \\
2.541 \\
1.589 \\
1.444 \\
1.431 \\
1.932 \\
1.551 \\
1.561 \\
.904 \\
1.557 \\
3.106\end{array}$ & $\begin{array}{r}1.182 \\
1.090 \\
.209 \\
.880 \\
1.444 \\
.933 \\
1.557 \\
1.190 \\
1.361 \\
.979 \\
1.693 \\
2.000 \\
1.773\end{array}$ & $\begin{array}{r}2.306 \\
1.000 \\
1.140 \\
2.650 \\
.970 \\
1.056 \\
1.946 \\
1.186 \\
1.217 \\
1.439 \\
.826 \\
1.556 \\
1.727\end{array}$ \\
\hline 28. Mean & .654 & .994 & .893 & 1.572 & 1.346 & 1.712 & 1.253 & 1.463 \\
\hline
\end{tabular}

Source: The marginal shares are from Lluch et al. (1977, Table 3.6). The income elasticities are derived using equation (11.3). 
Notwithstanding its popularity, LES has its drawbacks. Perhaps the most important is the parameterization whereby the marginal shares are treated as constants. It is clear from (11.3) that the constancy of the marginal share implies that the income elasticity is inversely proportional to the corresponding budget share. This can give rise to problems when income is subject to large changes.

Consider the case of food, the dominant commodity in most countries. By Engel's law, food is a necessity (i.e., $\eta_{i}<1$ for $i=1$, representing food, the first commodity). Consequently, if prices remain constant, a rise in income causes consumption of food to increase less than proportionately so that its budget share falls. It then follows from $\eta_{1}=\theta_{1} / w_{1}$ that as the consumer becomes more affluent, the food income elasticity rises when $\theta_{1}$ is specified as a constant. That is, food becomes less of a necessity or more of a luxury with increasing income. This behaviour of the elasticity under LES is clearly implausible, a criticism made by Theil (1983) .

To illustrate, suppose we take tastes to be the same internationally (following the advice of Section 8), pool the LPW data across countries and then apply LES. This model would have the same parameters for each country. From column 2 of Table 19, the mean of the individual-country estimates of the food marginal share is .29. It is sufficient for purposes of illustration to use this as the cross-country value of this share. The observed food budget shares are given in Table 16: For the US, consumers spend 27 percent of their income on food, while the Koreans spend 60 percent. Thus we have: 
US $\quad$ Korea

$\begin{array}{lll}\text { Food marginal share } \theta_{1} & .29 & .29 \\ \text { Food budget share } \overline{\mathrm{w}}_{1 \mathrm{c}} & .27 & .60 \\ \text { Food income elasticity } & & \\ \quad \eta_{1 \mathrm{c}}=\theta_{1} / \overline{\mathrm{w}}_{1 \mathrm{c}} & 1.07 & .48\end{array}$

The above calculation reveals a spectacular disparity in the income elasticity of food. This elasticity for the US (the richest country) is more than twice that for Korea (the poorest). In fact, if we take the results literally, food is a luxury in the US! Note also that these elasticities are nothing like the individual-country estimates given in the lower part of column 2 of Table 19. Clearly, LES fails in this cross-country application.

\section{More on Working's Mode1}

In the previous section we saw that the behaviour of income elasticities implied by LES is unattractive. It should be added that the Rotterdam model (Barten, 1964, Theil, 1965), in which the marginal shares are also specified as constants, suffers from the same defect. In this section we show that Working's (1943) model circumvents the problem.

Working's model is given by equation (4.1) which we reproduce here: 


$$
\mathrm{w}_{\mathbf{i}}=\alpha_{\mathbf{i}}+\beta_{\mathbf{i}} \log \mathbb{M},
$$

$i=1, \ldots, n$.

Using $w_{i}=p_{i} q_{i} / \mathbb{M}$ in (12.1) and multiplying both sides by $\mathbb{H}$, we get

$$
p_{i} q_{i}=a_{i} \mathbb{H}+\beta_{i} \mathbb{M} \log \mathbb{M} .
$$

Differentiating both sides of this equation with respect to $\mathbb{I}$ and using (12.1), we obtain the marginal share of good $i$ implied by Working's model,

$$
\theta_{i}=w_{i}+\beta_{i} .
$$

Since the budget share $\mathrm{w}_{i}$ is not constant, neither is the marginal share under Working's model.

The income elasticity is the ratio of the marginal share to the corresponding budget share, $\eta_{i}=\theta_{i} / w_{i}$. It then follows from (12.2) that the income elasticity of $i$ implied by Working'g model is

$$
\eta_{i}=1+\frac{\beta_{i}}{w_{i}} .
$$

This shows that a commodity is a necessity (luxury) if $\beta_{i}$ is negative (positive). As the budget share of a necessity falls with increasing income, this expression implies that the income elasticity of such a good falls when income increases. By a similar argument, the income elasticities of luxuries also fall as income rises. That is, as the consumer becomes more affluent, all goods become less luxurious under Working's model, which is plausible. This result is in contrast to 
the behaviour of the income elasticities from LES and the Rotterdam model, in which the marginal shares are constants. Therefore, Working's model is a plausible alternative to taking the marginal shares as constants.

From equation (12.2), in Working's model the marginal share differs from the corresponding budget share by a constant,

$$
\beta_{i}=\theta_{i}-w_{i}
$$

Thus, if we have a number of estimates of the marginal share for commodity $i, \theta_{i c}, c=1, \ldots, N$, as well as $w_{i c}, c=1, \ldots, N$, we can obtain a simple estimate of $\beta_{i}$ by averaging,

$$
\hat{\beta}_{i}=\frac{1}{N} \sum_{c=1}^{N}\left(\theta_{i c}-w_{i c}\right) .
$$

To implement (12.4) for food, we use the $\mathrm{N}=13$ countries from LPW, the estimates of the $\theta_{i c}$ 's given in Table 19 and the corresponding budget shares from Table 16. (Note that as the estimates of the marginal shares are obtained country-by-country by LPW, each value is independent of the other.) Table 20 contains the results for food $(i=1)$. The standard errors given in the last row indicate that the differences $\left(\theta_{1 c}-w_{1 c}\right)$ are less variable than the marginal shares $\theta_{1 c}$, which points in the direction of parameterizing on $\beta_{1}$, rather than $\theta_{1}$. Recall from Section 4 that previous estimates of Working's income coefficient for food $\left(\beta_{1}\right)$ were closely clustered around the value -.15. The new estimate of this coefficient given in row 14 of column 4 of Table 20 is -.14 with 
Table 20

Marginal Shares and Budget Shares

of Food for 13 Countries

\begin{tabular}{lccc}
\hline Country & $\begin{array}{c}\text { Marginal } \\
\text { share }\end{array}$ & $\begin{array}{c}\text { Budget } \\
\text { share }\end{array}$ & $\begin{array}{c}\text { Excess of } \\
\text { marginal share } \\
\text { over } \\
\text { budget share }\end{array}$ \\
(1) & $(2)$ & $(3)$ & $(4)$ \\
\hline 1. US & & & \\
2. Sweden & .090 & .267 & -.177 \\
3. Australia & .143 & .366 & -.088 \\
4. UK & .120 & .333 & -.190 \\
5. Israel & .210 & .397 & -.109 \\
6. Italy & .401 & .319 & -.062 \\
7. Puerto Rico & .177 & .463 & -.179 \\
8. Ireland & .315 & .356 & -.177 \\
9. Greece & .341 & .492 & -.127 \\
10. South Africa & .295 & .468 & -.073 \\
11. Panama & .418 & .368 & -.037 \\
12. Thailand & .482 & .455 & -.094 \\
13. Korea & .434 & .576 & -.165 \\
14. Mean & .285 & .599 & -.135 \\
15. Standard error & & .018 \\
$\quad$ of the mean & .034 & .420 & \\
& & .026 & \\
\hline
\end{tabular}

Source: Columns 2 and 3, Lluch et al. (1977, Tables 3.6 and 3.3).

standard error .02, which is obviously in close agreement with the other estimates. The emergence of more or less the same value of $\beta_{i}$ in a wide variety of applications seems to give reassurance that some fundamental behavioural response is being measured here, a response which is more or less constant across consumers, time and countries. 
LPW consider the following relation between the food marginal share, $\theta_{1}$, and GNP per capita, $\mathrm{Y}$ :

$$
\theta_{1}=\mathrm{a}+\mathrm{b} \log \mathrm{Y}
$$

where $\mathrm{a}$ and $\mathrm{b}$ are constants. To interpret this equation, we combine (12.1) and (12.2) for $i=1$ to yield

$$
\theta_{1}=\lambda+\beta_{1} \log \mathbb{M}
$$

where $\lambda=\alpha_{1}+\beta_{1}$ is a constant and $\beta_{1}$ is Working's income coefficient for food. A comparison of (12.5) and (12.6) reveals that under the not unreasonable assumption that total expenditure $\mathbb{M}$ is proportional to $\mathrm{Y}$, the coefficient $\mathrm{b}$ in (12.5) is interpreted as $\beta_{1}$.

LPW (1977, Table 3.11, p. 52) apply (12.5) to their 17 countries and obtain the LS estimate of $b$ of -.179 with standard error .045 . Using the 13 countries listed in Table 15, GNP of that table and the food marginal shares of Table 19, yields a b-estimate of -.103 with standard error .023. Here again, these are insignificantly different from the centre- of-gravity value of -.15.

We return to (12.4), the estimator of Working's income coefficient for good $i$, and use the LPW data to implement it for $i=1, \ldots, 8$ commodities. The procedure is exactly the same as that used for food and Table 21 contains the results. The estimates of $\beta_{i}$ for food and housing are negative; that for clothing is close to zero; and the remaining ones are positive. This shows that food and housing are necessities, clothing is a borderline case, while the other five goods are luxuries. This is in agreement with the average income 
Table 21

Estimates of Working's Income Coefficients from LPW Data

(Standard errors in parentheses)

\begin{tabular}{lc}
\hline Commodity & $\begin{array}{c}\text { Income } \\
\text { coefficient } \\
\beta_{i} \\
1)\end{array}$ \\
\hline 1. Food & $(2)$ \\
2. Clothing & $-.135(.018)$ \\
3. Housing & $-.001(.009)$ \\
4. Durables & $-.013(.014)$ \\
5. Personal care & $.028(.005)$ \\
6. Transport & $.019(.007)$ \\
7. Recreation & $.066(.012)$ \\
8. Other services & $.019(.008)$ \\
\end{tabular}

elasticities from LPW given in Table 19.

To explore further the implications of the cross-country $\beta_{i}$-estimates, we compute the implied marginal shares and income elasticities and Table 22 contains the results. These are to be compared with the LPW values given in Table 19. We can regard the values in Table 22 as "fitted" and those in Table 19 as "observed". The correlation coefficients between the two sets of marginal shares are:

$\begin{array}{llll}\text { Food } & .86 & \text { Personal care } & .79 \\ \text { Clothing } & .31 & \text { Transport } & .65 \\ \text { Housing } & .64 & \text { Recreation } & .73 \\ \text { Durables } & .61 & \text { 0ther services } & .82\end{array}$


Table 22

Second Set of Marginal Shares and Income Elasticities of 8 Commodities for 13 Countries

Country

(1)

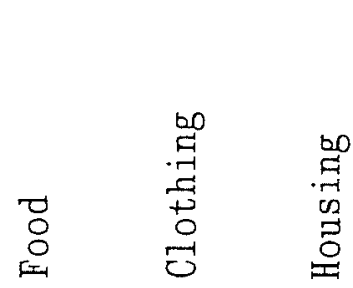

(2)

(3)

(4)

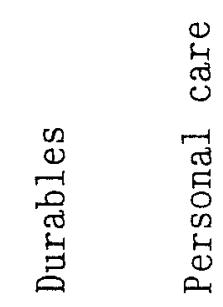

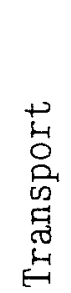

(7)

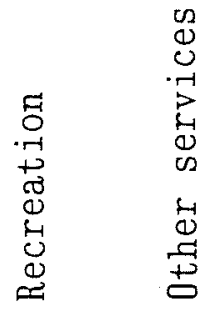

(5)

(6)

(8)

\section{Marginal shares}

$\begin{array}{lcccccccc}\text { 1. US } & .132 & .094 & .214 & .101 & .100 & .218 & .074 & .067 \\ \text { 2. Sweden } & .231 & .114 & .146 & .098 & .056 & .208 & .108 & .042 \\ \text { 3. Australia } & .198 & .109 & .114 & .106 & .076 & .197 & .062 & .139 \\ \text { 4. UK } & .262 & .106 & .170 & .094 & .042 & .175 & .094 & .058 \\ \text { 5. Israel } & .184 & .093 & .179 & .102 & .085 & .139 & .100 & .118 \\ \text { 6. Italy } & .328 & .100 & .153 & .060 & .082 & .147 & .094 & .036 \\ \text { 7. Puerto Rico } & .221 & .105 & .140 & .097 & .088 & .189 & .107 & .055 \\ \text { 8. Ireland } & .357 & .099 & .115 & .085 & .032 & .154 & .082 & .077 \\ \text { 9. Greece } & .333 & .121 & .170 & .067 & .055 & .135 & .080 & .041 \\ \text { 10. South Africa } & .233 & .117 & .154 & .106 & .067 & .198 & .066 & .059 \\ \text { 11. Panama } & .320 & .073 & .154 & .092 & .066 & .160 & .094 & .041 \\ \text { 12. Thailand } & .441 & .083 & .067 & .060 & .075 & .145 & .094 & .036 \\ \text { 13. Korea } & .464 & .103 & .101 & .056 & .061 & .113 & .063 & .040 \\ & & & & & & & & \\ \text { 14. Mean } & .285 & .101 & .144 & .086 & .068 & .168 & .086 & .062\end{array}$

Income elasticities

$\begin{array}{lcccccccc}\text { 15. US } & .494 & .989 & .943 & 1.384 & 1.235 & 1.434 & 1.345 & 1.367 \\ \text { 16. Sweden } & .631 & .991 & .918 & 1.400 & 1.514 & 1.465 & 1.213 & 1.750 \\ \text { 17. Australia } & .595 & .991 & .898 & 1.359 & 1.333 & 1.504 & 1.442 & 1.149 \\ \text { 18. UK } & .660 & .991 & .929 & 1.424 & 1.826 & 1.606 & 1.253 & 1.450 \\ \text { 19. Israel } & .577 & .989 & .932 & 1.378 & 1.288 & 1.904 & 1.235 & 1.180 \\ \text { 20. Italy } & .708 & .990 & .922 & 1.875 & 1.302 & 1.815 & 1.253 & 2.000 \\ \text { 21. Puerto Rico } & .621 & .991 & .915 & 1.406 & 1.275 & 1.537 & 1.216 & 1.486 \\ \text { 22. Ireland } & .726 & .990 & .898 & 1.491 & 2.462 & 1.750 & 1.302 & 1.305 \\ \text { 23. Greece } & .712 & .992 & .929 & 1.718 & 1.528 & 1.957 & 1.311 & 1.783 \\ \text { 24. South Africa } & .633 & .992 & .922 & 1.359 & 1.396 & 1.500 & 1.404 & 1.439 \\ \text { 25. Panama } & .703 & .986 & .922 & 1.438 & 1.404 & 1.702 & 1.253 & 1.783 \\ \text { 26. Thailand } & .766 & .988 & .838 & 1.875 & 1.339 & 1.835 & 1.253 & 2.000 \\ \text { 27. Korea } & .775 & .990 & .886 & 2.000 & 1.452 & 2.404 & 1.432 & 1.818 \\ & & & & & & & & \\ \text { 28. Mean } & .662 & .990 & .912 & 1.547 & 1.489 & 1.724 & 1.301 & 1.578\end{array}$

The marginal shares are computed from equation (12.2) with the observed budget shares given in Table 16 and the $\beta_{i}$-estimates given in Table 21 . The income elasticities are computed from (12.3) using the the same 
As can be seen, except for clothing, the two sets of marginal shares agree well which tends to support the idea that Working's model can be satisfactorily applied to the world as a whole (the "world" being the $13 \mathrm{LPW}$ countries).

\section{A World Demand System}

The results of the previous section are based on income responses of demand which hold constant prices. Those results are sufficiently encouraging to proceed further and extend the approach to deal simultaneously with the effects of income and prices. In this section we ask the question, how much of the cross-country variation in consumption patterns is explained by differences in incomes and prices? To do this we employ a simple extension of Working's model which contains a price substitution term.

Our starting point is equation (6.3), the double-log demand equation for good $i$, which we reproduce here:

$$
\log q_{i}=a_{i}+\eta_{i} \log Q+\sum_{j=1}^{n} \eta_{i j}^{\prime} \log p_{j},
$$

where $a_{i}$ is an intercept; $\eta_{i}$ is the income elasticity of $i$; $Q$ is real income; and $\eta_{i j}^{\prime}$ is the $(i, j)^{\text {th }}$ compensated price elasticity. To apply this equation to the LPW cross-country data, we write it in terms of changes over time; add to the variables and elasticities a country subscript $\mathrm{c}(\mathrm{c}=1, \ldots, 13)$; and set $\mathrm{n}=8$ commodities. This yields 


$$
\mathrm{Dq}_{\mathrm{ic}}=\eta_{\mathrm{ic}} \mathrm{DQ_{ \textrm {C } }}+\sum_{\mathrm{j}=1}^{8} \eta_{\mathrm{ijc}}^{\prime} \mathrm{Dp} \mathrm{jc}_{\mathrm{jc}}
$$

where $\mathrm{D}$ is the log-change operator; and $\mathrm{DQ}_{\mathrm{C}}$ is the Divisia volume index of the change in real income. Note that as log-changes are unit free, all variables in (13.1) are directly comparable across countries, independent of the different currency units.

The demand system (13.1) for $i=1, \ldots, 8$ contains an $8 \times 8$ matrix of price elasticities $\left[\eta_{i j c}^{\prime}\right]$ for each of the 13 countries. To reduce the number of unknowns, we shall invoke the assumption of preference independence. As discussed in Section 6, the price elasticities for country $c$ then take the form

$$
\eta_{i j c}^{\prime}=\phi \eta_{i c}\left(\delta_{i j}-\theta_{j c}\right), \quad \quad i, j=1, \ldots, 8,
$$

where $\phi$ is the income flexibility (the reciprocal of the income elasticity of the marginal utility of income); $\delta_{i j}$ is the Kronecker $\operatorname{delta}\left(\delta_{i j}=1\right.$ if $i=j,=0$ otherwise $)$; and $\theta_{j c}$ is the $j^{\text {th }}$ marginal share in $c$. The use of the assumption of preference independence is probably not too bad here as the 8 commodities in the LPW database are broad aggregates. Note that as $\phi$ in equation (13.2) does not have a country subscript, it as specified as a constant; this is in agreement with the discussion of Section 9 above.

Let $\mathrm{Dq}_{\mathrm{ic}}$ be observed value of the log-change in consumption of $i$ in $c$; and $\eta_{i c} D_{c}+\Sigma_{j=1}^{8} \eta_{i j c}^{\prime} D p_{j c}$ be the corresponding fitted value when numerical values are used for the elasticities. The values of the variables $\mathrm{Dq}_{\mathrm{ic}}$ and $\mathrm{Dp}_{\mathrm{ic}}$ are given in Table 17 , while those of $\mathrm{DQ}_{\mathrm{C}}$ are in column 3 of Table 18. If $e_{i c}$ is the difference between the 
observed and fitted values, then one way to measure the quality of the predictions for commodity $i$ is the root-mean-squared error,

$$
\operatorname{RMSE}_{i}=\sqrt{\frac{1}{13} \sum_{\mathrm{c}=1}^{13} \mathrm{e}_{\mathrm{ic}}^{2}} .
$$

The performance of the system as a whole can then be measured by the budget-share-weighted average of the RMSE $_{i}$,

$$
\operatorname{RMSE}=\sum_{i=1}^{8} \overline{\mathrm{w}}_{i} \mathrm{RMSE}_{i},
$$

where $\overline{\mathrm{w}}_{i}$ is the cross- country average of the budget share of $i$, given in the last row of Table 16.

We first use the LPW estimates of the income elasticities given in the lower half of Table 19, the marginal shares of the upper half of that table and set the income flexibility $\phi=-.5$, the value recommended in Section 9. Column 2 of Table 23 contains the results. As can be seen, food and housing share the lowest value of the RMSE of about .5 percent; the largest RMSE is 1.9 percent for durables; while the weighted average is .7 percent. 0verall, these RMSEs are very low. However, it should be kept in mind that underlying these predictions are $n-1=7$ free income elasticities (one is constrained by $\Sigma_{i=1}^{8} \mathrm{w}_{i} \eta_{i}=1$ ) for each of the 13 countries, plus a value of $\phi$. Consequently, the column 2 results are based on $7 \times 13+1=92$ free parameters. As the income elasticities are unconstrained across countries, in a certain sense tastes are not constant in the demand equations underlying the results of column 2 . 
Table 23

Quality of Predictions of Demand Equations for 8 Commodities in 13 Countries

(Root-mean-squared errors $\times 100)$

\begin{tabular}{lccc}
\hline Commodity & $\begin{array}{c}\eta_{\text {ic }}=\mathrm{LPW} \\
\phi=-.5\end{array}$ & $\begin{array}{c}\eta_{\mathrm{ic}}=1 \\
\phi=-1\end{array}$ & $\begin{array}{c}\eta_{\mathrm{ic}}=\mathrm{WM} \\
\phi=-.5\end{array}$ \\
& $(2)$ & $(3)$ & $(4)$ \\
\hline 1. Food & & & \\
2. Clothing & .51 & 1.41 & .64 \\
3. Housing & .61 & 1.20 & 1.02 \\
4. Durables & .51 & 2.30 & 1.23 \\
5. Personal care & 1.89 & 1.63 & 1.70 \\
6. Transport & 1.15 & 2.33 & 2.41 \\
7. Recreation & 1.01 & 3.43 & 1.73 \\
8. Other services & .62 & 1.79 & 1.28 \\
& .88 & 2.42 & 2.37 \\
9. Weighted mean & .71 & 1.86 & 1.15 \\
& & & \\
\hline
\end{tabular}

As the demand equations are formulated in log-changes, the RMSEs $\times 100$ are (approximately) RMS percentage prediction errors. The notation $\eta_{\text {ic }}=\mathrm{LPW}$ denotes that the income elasticities used for the predictions are the LPW estimates given in the lower part of Table 19 ; and $\eta_{i c}=$ WM denotes that the income elasticities are from Working's model, given in the lower part of Table 22.

Next, we specify that all income elasticities are unity, so that the marginal shares are equal to the corresponding budget shares, and $\phi=-1$. This is a naive extrapolation corresponding to no-change of the budget shares (Theil, 1975/76, p. 219 of Volume 1), which serves 
as a standard of reference. The results in column 3 of Table 23 show that most of the RMSE $_{i}$ increase substantially in relation to those of column 2. The weighted-average RMSE of 1.9 percent in column 3 is about 2.5 times larger than its column 2 counterpart.

Finally, we use the income elasticities and marginal shares implied by Working's model (given in Table 22) and $\phi=-.5$. Here tastes are taken to be constant as the income elasticities (and the marginal shares) are based on coefficients from Working's model, $\beta_{1}, \ldots, \beta_{8}$, which are the same for all countries. Column 4 of Table 23 contains the results. These RMSEs are mostly substantially lower than those of column 3, where all elasticities are unitary. At the same time however, the column 4 values are in general higher than the LPW values given in column 2; the weighted-average RMSE in column 4 of 1.2 percent is about 65 percent higher than its column 2 counterpart. Nevertheless, the average RMSE of 1.2 percent is an excellent result keeping in mind the diversity of countries involved. In addition, the predictions of column 4 are based on only 8 free parameters ( $7 \beta_{i}$ 's, as one is constrained by $\sum_{i=1}^{8} \beta_{i}=0$, plus $\left.\phi\right)$. Consequently, the increase in the average RMSE from .7 percent (in column 2) to 1.2 percent (column 4) is perfectly acceptable given that the number of free parameters falls from 92 to 8 .

It is thus fair to make the strong claim that this approach allows world consumption patterns to be adequately described with only 8 parameters. Of course, the qualifications to this claim are obvious: Here we are dealing with broad commodity groups and the "world" is made up of only 13 representative countries. (For a more elaborate analysis of the LPW data, see Chen, 1991, and S. Selvanathan, 1988b.) 


\section{$\underline{\text { References }}$}

Aasness, J. and A. Rodseth (1983). "Engel Curves and Systems of Demand Functions." European Economic Review 20: 95-121.

Anderson, G. and R. Blundel1 (1983). "Testing Restrictions in a Flexible Dynamic Demand System: An Application to Consumers' Expenditure in Canada.". Review of Economic Studies 50: 397-410.

Attfield, C.L.F. (1985). "Homogeneity and Endogeneity in Systems of Demand Equations." Journal of Econometrics 27: 197-209.

Barnett, W.A. (1981). Consumer Demand and Labour Supply: Goods, Monetary Assets and Time. Amsterdam: North-Holland Publishing Company .

Barten, A.P. (1964). "Consumer Demand Functions Under Conditions of Almost Additive Preferences." Econometrica 32: 1-38.

(1977). "The Systems of Consumer Demand Functions Approach: A Review." Econometrica 45: 23-51.

Bera, A.K., R.P. Byron and C.M. Jarque (1981). "Further Evidence on Asymptotic Tests for Homogeneity and Symmetry in Large Demand Systems." Economics Letters 8: 101-5.

Bewley, R.A. (1983). "Tests of Restrictions in Large Demand Systems." European Economic Review 20: 257-69.

(1986). Allocation Models: Specification, Estimation and Applications. Cambridge, Mass.: Ballinger Publishing Co.

and G. Elliott (1989). "The Rejection of Homogeneity in Demand and Supply Analysis: An Explanation and Solution." Discussion Paper No. 89/2, School of Economics, The University of New South Wales. 
Blanciforti, L. and R. Green (1983). "An Almost Ideal Demand System Incorporating Habits: An Analysis of Expenditures on Food and Aggregrate Commodity Groups." Review of Economics and Statistics 65: 511-15.

Blunde11, R. (1988). "Consumer Behaviour: Theory and Empirical Evidence -- A Survey." Economic Journal 98: 16-65.

Brown, A. and A. Deaton (1972). "Surveys in Applied Economics: Models of Consumer Behaviour." Economic Journal 82: 1145-236.

Chen, D.L. (1991). "Undersized Samples and Demand Analysis." Discussion Paper No. 91.18, Department of Economics, The University of Western Australia.

Christensen, L.R., D.W. Jorgenson and L.J. Lau (1975). "Transcendental Logarithmic Utility Functions." American Economic Review 65: 367-83.

Chung, C-F. and E. Lopez (1988). "A Regional Analysis of Food Consumption in Spain." Economics Letters 26: 209-13.

Clements, K.W. (1982). "Divisia Moments of Australian Consumption." Economics Letters 9: 43-48.

(1983). "The Demand for Energy Used in Transport." Australian Journal of Management 8: 27-56.

(1987). "Alternative Approaches to Consumption Theory." Chapter 1 in H. Theil and K.W. Clements Applied Demand Analysis: Results from System-Wide Approaches. Cambridge, Mass.: Ballinger Publishing Co., pp. 1-35.

E.A. Selvanathan and S. Selvanathan (1992). "Henri Theil's Contributions to Demand Analysis." In R.A. Bewley and T.V. Hoa (eds) Contributions to Consumer Demand and Econometrics: Essays in Honour of Henri Theil. London: MacMillan, pp. 74- 104. 
Deaton, A.S. (1974). "A Reconsideration of the Empirical Implications of Additive Preferences." Economic Journal 84: 338-48.

(1975). Models and Projections of Demand in Post War Britain. London: Chapman and Hall.

(1986). "Demand Analysis." In Z. Griliches and M.D. Intriligator (eds) Handbook of Econometrics. Volume III. Amsterdam: North-Holland Publishing Company, pp. 1768-839.

(1987). "Econometric Issues for Tax Design in Developing Countries." In D. Newbery and N. Stern (eds) The Theory of Taxation for Developing Countries. New York: 0xford University Press, pp. 92-113.

and J. Muellbauer (1980a). Economics and Consumer Behaviour. Cambridge: Cambridge University Press.

and J. Muellbauer (1980b). "An Almost Ideal Demand System." American Economic Review 70: 312-26.

DeJanvry, A., J. Bieri and A. Nunez (1972). "Estimation of Demand Parameters Under Consumer Budgeting: An Application to Argentina." American Journal of Agricultural Economics 54: 422-30.

Dixon, P.B., B.R. Parmenter, J. Sutton and D.P. Vincent (1982). ORANI: A Multisectoral Model of the Australian Economy. Amsterdam: North-Holland Publishing Company.

Finke, R., L.R. Flood and H. Theil (1984). "Maximum Likelihood and Instrumental Variable Estimation of a Consumer Demand System for Japan and Sweden." Economics Letters 15: 13-19.

Frisch, R. (1959). "A Complete Scheme for Computing A11 Direct and Cross Demand Elasticities in a Model with Many Sectors." Econometrica 27: 177-96. 
Goldberger, A.S. (1987). Functional Form and Utility: A Review of Consumer Demand Theory. Boulder and London: Westview Press.

and T. Gamaletsos (1970). "A Cross-Country Comparison of Consumer Expenditure Patterns." European Economic Review 1: 357-400.

Houthakker, H.S. (1957). "An International Comparison of Household Expenditure Patterns, Commemorating the Centenary of Engel's Law." Econometrica 25: 532- 51 .

Keuzenkamp, H.A. and A.P. Barten (1991). "Rejection Without Falsification: 0n the History of Testing the Homogeneity Condition in the Theory of Consumer Demand." Department of Economics, Tilburg University and Department of Economics, Catholic University Leuven.

Klein, L.R. and H. Rubin (1948). "A Constant-Utility Index of the Cost of Living." Review of Economic Studies 15: 84- 87.

Kravis, I.B., A.W. Heston and R. Summers (1982). World Product and Income: International Comparisons of Real Gross Product. Baltimore, Md.: The John Hopkins University Press.

Laitinen, K. (1978). "Why is Demand Homogeneity So Often Rejected?" Economics Letters 1: 187-91.

Leser, C.E.V. (1963). "Forms of Engel Functions." Econometrica 31: 694- 703 .

Lluch, C. (1973). "The Extended Linear Expenditure System." European Economic Review 4: 21-32.

and A.A. Powell (1975). "International Comparisons of Expenditure Patterns." European Economic Review 5: 275- 303. 
Lluch, C, A.A. Powell and R.A. Williams (1977). Patterns in Household Demand and Saving. 0xford: 0xford University Press.

Marquez, J. and D. Vining (1984). "Inflation and Relative Price Change: A Survey of the Literature." In. M.Ballabon (ed) Economic Perspective: An Annual Survey of Economics 3. New York: Harwood Academic Publishers.

Meisner, J.F. (1979a). "The Sad Fate of the Asymptotic Slutsky Symmetry Test for Large Systems." Economics Letters 2: 231-33.

(1979b). "Divisia Moments of U.S. Industry, 1947-1978." Economics Letters 4: 239-42.

Musgrove, P. (1985). "Household Food Consumption in the Dominican Republic: Effects of Income, Price and Family Size." Economic Development and Cultural Change 34: 83-101.

Parks, R.W. (1969). "Systems of Demand Equations: An Empirical Comparison of Alternative Functional Forms." Econometrica 37: 629- 50 .

Phlips, L. (1974). Applied Consumption Analysis. Amsterdam: North-Holland Publishing Company. Second edition 1983.

Pigou, A.C. (1910). "A Method of Determining the Numerical Values of Elasticities of Demand." Economic Journal 20: 636-40.

Pollak, R.A. and T.J. Wales (1969). "Estimation of the Linear Expenditure System." Econometrica 37: 611-28.

and T.J. Wales (1987). "Pooling International Consumption Data." Review of Economics and Statistics 69: 90-99.

Powell, A.A. (1974). Empirical Analytics of Demand Systems. Lexington, Mass.: D.C. Heath and Company. 
Selvanathan, E.A. (1987). Explorations in Consumer Demand. Ph.D. Thesis, Murdoch University, Western Australia.

Selvanathan, S. (1987a) . "Do OECD Consumers Obey Demand Theory?" Discussion Paper No. 87.04, Department of Economics, The University of Western Australia.

(1987b). "A Monte Carlo Test of Preference Independence." Economics Letters 25: 259-61.

(1987c). "How Similar are 0ECD Consumers?" Discussion Paper No. 87.08, Department of Economics, The University of Western Australia.

(1987d). "Further Evidence on the Frisch Conjecture." Discussion Paper No. 87.10, Department of Economics, The University of Western Australia.

(1988a). "Empirical Regularities in 0ECD Consumption." Discussion Paper No. 88.01, Department of Economics, The University of Western Australia.

(1988b). A System-Wide Analysis of International and Interregional Consumption Patterns. Ph.D. Thesis, The University of Western Australia.

Stening, K. (1985). "OECD Consumption: A Database." Unpublished manuscript, Department of Economics, The University of Western Australia.

Stigler, G.J. and G.S. Becker (1977). "De Gustibus Non Est Disputandum." American Economic Review 67: 79-90.

Stone, R. (1954). "Linear Expenditure Systems and Demand Analysis: An Application to the Pattern of British Demand." Economic Journal 64: 511-27. 
Summers, R. and A. Heston (1984). "Improved International Comparisons of Real Product and Its Composition: 1950-1980." Review of Income and Wealth $30: 207-68$.

Theil, H. (1965). "The Information Approach to Demand Analysis." Econometrica 33: 67-87.

(1967). Economics and Information Theory. New York: Elsevier/North-Holland, Inc., and Amsterdam: North-Holland Publishing Company.

$(1975 / 76)$. Theory and Measurement of Consumer Demand. Two volumes. Amsterdam: North-Holland Publishing Company.

(1980). The System-Wide Approach to Microeconomics. Chicago: The University of Chicago Press.

(1983). "World Product and Income: A Review Article." Journal of Political Economy 91: 505- 17.

(1987a). "Evidence from International Consumption Comparisons." Chapter 2 in H. Theil and K.W. Clements Applied Demand Analysis: Results from System-Wide Approaches. Cambridge, Mass.: Ballinger Publishing Co., pp. 37-100.

(1987b). "The Econometrics of Demand Systems." Chapter 3 in H. Theil and K.W. Clements Applied Demand Analysis: Results from System-Wide Approaches. Cambridge, Mass.: Ballinger Publishing Co., pp. 101-62.

and R.B. Brooks (1970/71). "How Does the Marginal Utility of Income Change when Real Income Changes?" European Economic Review 2: 218-40.

C-F. Chung and J.L. Seale, Jr. (1989). International Evidence on Consumption Patterns. Greenwich, Connecticut: JAI Press, Inc. 
Theil, H. and K.W. Clements (1987). Applied Demand Analysis: Results from System-Wide Approaches. Cambridge, Mass.: Ballinger Publishing Co.

and R. Finke (1984). "A Time-Series Analysis of a Demand System Based on Cross-Country Coefficient Estimates." Economics Letters 15: 245-50.

, J.L. Seale, Jr. and C-F. Chung (1987). "A Regional Analysis of Food Consumption in China." Empirical Economics 12: 129-35.

and F.E. Suhm (1981). International Consumption Comparisons: A System-Wide Approach. Amsterdam: North-Holland Publishing Company .

Working, H. (1943). "Statistical Laws of Family Expenditure." Journal of the American Statistical Association 38: 43-56.

Yoshihara, K. (1969). "Demand Functions: An Application to the Japanese Expenditure Pattern." Econometrica 37: 257-74. 